\title{
USING DISCLOSURE TO ACTIVATE THE BOARD OF DIRECTORS*
}

\author{
Elliott J. Weiss $\dagger$ \\ Donald E. Schwartz $\dagger$
}

\section{INTRODUCTION}

The theme of this article can be stated simply: In order to improve the manner in which boards of directors function and to ensure that important information about boards is made available to investors, the Securities and Exchange Commission should require reporting companies to disclose considerably more information about their boards of directors.

There are three concerns which underlie this proposal. First, ineffective performance by many corporate boards leads to below optimal corporate efficiency. Second, information about boards of directors that is potentially important to investment decisions is not now available to the public. Third, the paucity of meaningful information that is available about boards serves to undermine the operation of a system of fair corporate suffrage.

This article is divided into two parts. The first sets forth our reasons for believing the SEC should require disclosure of additional information about the boards of all reporting companies. It includes discussion of:

(a) the background of the disclosure provisions of the Securities Exchange Act of 1934, which makes clear that the SEC can properly mandate disclosure for the purpose of influencing corporate conduct where the information to be disclosed is important to decisions to be made by investors;

(b) the relevance of a properly functioning board to the efficient operation of corporations in a free-market economy as well as to the integrity of the disclosure process administered by the SEC;

(c) the importance of information about boards to individuals and institutions that make investment, disinvestment, and corporate suffrage decisions;

(d) the advantages of using disclosure rather than either ad hoc enforcement or mandatory requirements to influence constructively the functioning of corporate boards of directors.

The second part of this article describes the elements of our proposed

\footnotetext{
* The authors were fortunate in having the research and editorial assistance of Gerard L. Hawkins, a third-year student at Georgetown University Law Center.

$\dagger$ Associate Professor of Law, Benjamin N. Cardozo School of Law, Yeshiva University. Prof. Weiss expresses appreciation to the Ford Foundation for its financial support to him over the period during which he prepared this article.

$+\dagger$ Professor of Law, Georgetown University Law Center.
} 
disclosure system-a system that focuses on the processes by which boards operate. We propose that the SEC require disclosure of information about individual nominees for election as directors, the procedures and criteria used by boards to select nominees, the organization and activities of boards, and the reason for all resignations of directors.

Our proposal is limited; it may be viewed by some as too limited when evaluated in terms of our concerns. We recognize that improving disclosure about corporate procedures cannot ensure an improvement in corporate conduct, particularly since altering the procedures themselves cannot give that assurance. However, there are many instances in which a legal system cannot assure a desired outcome but is limited to creating an environment in which that outcome is more likely. "In the case of boards of directors, directors cannot be made to perform responsibly simply by being told they must do so, and the threat of liability has failed to accomplish desired results. The time has come, we believe, to attempt to stimulate constructive change by relying on disclosure.

The Case for a Disclosure Approach

\section{A. Legislative History and Background}

An examination of the background of the federal securities laws makes it clear that Congress was aware of the power of disclosure when it passed those laws in the midst of the Great Depression. More specifically, Congress anticipated that the disclosures to be required by the SEC would influence investors' views about the importance of certain information and would encourage or discourage certain kinds of corporate conduct.

The Commission used its disclosure authority for these purposes and, in general, SEC disclosure requirements seemingly calculated to influence corporate conduct were challenged only when it appeared unlikely that the data to be disclosed should or would be considered important by investors.

\section{Legislative History}

The formal legislative documents pertaining to the securities laws indicate that Congress anticipated that disclosure would influence the activities of corporate directors, but do not make clear how Congress thought that process would work. The House Interstate and Foreign Commerce Committee, in its report on the Securities Act of 1933, stated, ${ }^{2}$

Honesty, care, and competence are the demands of trusteeship. These demands are made by the bill on the directors of the issuer. . . If it be said that

1. See C. Schultze, Public Use of Private Interests (1977).

2. H.R. ReP. No. 85, 73d Cong., lst Sess. 5 (1933). 
the imposition of such responsibility upon these persons will be to alter corporate organization and corporate practice in this country, such a result is only what your committee expects .... Directors should assume the responsibility of directing and if their manifold activities make real directing impossible, they should be held responsible to the unsuspecting public for their neglect.

In adopting the 1934 Act Congress stated that its objective in the regulation of proxy solicitation ${ }^{3}$ was "fair corporate suffrage." 4 The House report did not elaborate on what was meant by that term, but did go on to discuss the existing obstacles to that objective. The concern was that insiders would have little difficulty retaining their control "without an adequate disclosure of their interest and without an adequate explanation of the management policies they intend to pursue."5 There was inadequate disclosure of the reasons for the solicitation of proxies and the use to which they would be put. The Senate report also noted that stockholders should be enlightened about the financial condition of the corporation and about "major questions of policy, which are decided at stockholders' meetings."6

\section{Literature of the Day}

While the legislative documents do not make clear how Congress believed disclosure would lead to fair corporate suffrage, a review of the literature of the day provides important insights into the expectations of the policymakers who fashioned the securities laws. Those policymakers clearly understood the manner in which the SEC would influence the behavior of corporations by use of its disclosure authority.

The framers of the securities laws were aware that attaining shareholder democracy, in the political sense of that term, was not a realistic objective. Professors Adolf A. Berle and Gardiner Means, the former a powerful member of the New Deal Brain Trust, in their classic work The Modern Corporation and Private Property, had demonstrated that control of the large corporation had become separated from its ownership. ${ }^{7}$ Berle and Means recognized that two approaches might be utilized to influence directors' conduct: stricter application of fiduciary principles and expanded disclosure requirements. ${ }^{8}$

Professor William Z. Ripley, whom Berle and Means acknowledged as the

3. Sec. Exch. Act of $1934, \S 14,48$ Stat. 895 (codified at 15 U.S.C. $\S 78$ n (1970))

4. H.R. Rep. No. 1383, 73d Cong., 2d Sess. 13-14 (1934).

5. Id.

6. S. ReP. No. 1455, 73d Cong., 2d Sess. 77 (1934).

7. A. Berle \& G. Means, The Modern Corporation and Private Property, chapters IV and $\mathrm{V}$ (1932).

8. Berle had written earlier that corporate powers of control were held in a fiduciary capacity and that the law must be used to constrain directors and managers in their exercise of corporate power. See Berle, Corporate Powers as Powers in Trust, 44 HARv. L. Rev. 1049 (1931). 
pioneer in their field, ${ }^{9}$ had emphasized earlier the merits of disclosure. ${ }^{10} \mathrm{He}$ made it clear, however, that while disclosure would influence corporate behavior, it was unlikely to do so through an upsurge in shareholder activism: ${ }^{11}$

No one believes that a great enterprise can be operated by town meeting. It never has been done successfully; nor will it ever be .... Nor is it true that the primary purpose of publicity, the sharing of full information with owners, is to enable these shareholders to obtrude themselves obsequiously upon their own managements.

Rather, Ripley noted, information about the corporation, its board, and its operations would have an impact because a select group of sophisticated investors would understand the information, would act on it, and also would translate it into terms meaningful to the mass of investors and disseminate the information to them. ${ }^{12}$ Thus, the work of Ripley, and Berle and Means, taken together, made clear that disclosure would promote corporate democracy not by stimulating ordinary shareholders to attend annual meetings and cast informed votes but through much more indirect and sophisticated mechanisms. ${ }^{13}$

The work of other scholars and commentators over the same period made clear that the SEC by requiring disclosure could be expected to influence both corporate conduct and investors' assessments of that conduct. The seminal observation in this regard was made by Louis D. Brandeis, who extolled the virtue of disclosure as a regulator in the classic statement, "Sunlight is the best disinfectant; electric light the best policeman." 14 Professor Allison Anderson,

9. Berle AND MEANS, supra note 7, at ix.

10. He wrote that "[s]tockholders are entitled to adequate information, and the state and general public have a right to the same privilege." W. Ripley, Main Street and Wall Street 165 (1926).

11. Id. at $168-69$.

12. Id. The observation anticipates by many years the proponents of the efficient-market theory. See Fama, Efficient Capital Markets: A Review of Theory and Empirical Work, 25 J. FinANCE 383 (1970). It is also consistent with the views of somewhat stronger believers in the efficacy of full disclosure that the principal value of disclosure is for the experts who distill the information and make it available to non-experts. Kripke, The Myth of the Informed Layman, 28 Bus. L. 631 (1973).

Perhaps Ripley's most far sighted suggestion, however, was one he partially attributed to Berle: to create a permanent agency to be more representative of the shareholders' interest. "Such a body, either created out of hand or else evolved from present boards of directors, might be expressly empowered in the charter to assume certain responsibilities and to perform certain functions by way of check-up, so to speak. Its primary function would have to do with adequate publicity through independent audit." W. RIPLEY, supra note 10, at 133. He saw little prospect of this with boards of directors as then constituted. Id. at 139.

13. The complementary views of Ripley, Berle, Means and other scholars were reflected in the substance of the federal securities laws adopted in 1933 and 1934. Knauss, A Reappraisal of the Role of Disclosure, 62 MiCH. L. REv. 607, 613-15 (1964).

14. L. Brandeis, Other People's Money 92 (1913). Brandeis had long since been appointed to the Supreme Court when the securities laws were passed, but the influence of his ideas was as strong as if he had been a member of Roosevelt's "Brain Trust." See 1 L. Loss, Securities Regulation 123 (2d ed. 1961). 
in her study of the securities laws, states that the decision by the Roosevelt administration and Congress to rely heavily on disclosure-rather than attempt direct substantive regulation of corporate conduct-reflected the influence of Brandeis' observation. ${ }^{15}$

That this was so, and that the SEC was expected to decide what corporate activities were in need of policing and to use disclosure to police them, are evidenced by the contemporary writing of two other scholars, both of whom were important in the Roosevelt administration and both of whom were subsequently named to the Supreme Court. After the adoption of the Securities Act in 1933, Professor Felix Frankfurter stated: ${ }^{16}$

The Securities Act may well exercise indirect but important influence . . . upon corporate managers. . . . By compelling full publicity of 'every essentially important element attending the issue of new securities' so that the public may have an opportunity to understand what it buys, the Act seeks to promote standards of competence and candor in dealing with the public. . . There is a shrinking quality to such transactions; to force knowledge of them into the open is largely to restrain their happening. Many practices safely pursued in private lose their justification in public. Thus social standards newly defined gradually establish themselves as new business habits.

Similarly, Professor William O. Douglas observed that ${ }^{17}$

[p]ublicity alone can accomplish much-not publicity in the sense of a registration in some dusty file in Washington or in some state capitol, but publicity in the sense of direct and unequivocal statement in the periodical reports to stockholders. . . That simple expedient will go far as a corrective of conditions which have been constantly recurring in our corporate history. Its prophylactic effects will equal in importance any other single measure which can be adopted.

Thus, it seems clear Congress fully understood the power of disclosure and the manner in which the SEC would influence corporate conduct by requiring disclosure.

\section{Subsequent Developments}

The view that disclosure is to be used by the SEC as a regulatory tool has gained widespread support. In the Disclosure Policy Study-known as the Wheat Report-the SEC's philosophy of disclosure was set forth as follows: ${ }^{18}$

15. Anderson, The Disclosure Process in Federal Securities Regulation: A Brief Review, 25 Hastings L.Q. 311, 318, 330 (1974). Anderson also notes that the choice of disclosure rather than direct regulation to achieve substantive goals was partly motivated by political considerations. Id. at 331 .

16. Frankfurter, The Federal Securities Act: II, Fortune, Aug. 1933, 53, at 55.

17. Douglas, Directors Who Do Not Direct, 47 HARv. L. Rev. 1305, 1323-24 (1934).

18. Disclosure Policy Study (Wheat Report) 10 (1969).

The deterrent capacity and objective of disclosure has been recognized by the courts. In Laurenzano v. Einbinder, 264 F. Supp. 356 (E.D.N.Y. 1968), a court refused to dismiss a complaint for lack of a causal relationship between an allegedly misleading proxy statement and 
The emphasis on disclosure rests on two considerations. One relates to the proper function of the Federal government in investment matters. Apart from the prevention of fraud and manipulation, the draftsmen of the ' 33 and '34 Acts viewed that responsibility as being primarily one of seeing to it that investors and speculators had access to enough information to enable them to arrive at their own rational decisions. The other, less direct consideration rests on the belief that appropriate publicity tends to deter questionable practices and to elevate standards of business conduct.

Where SEC disclosure requirements or proposed requirements have been the subject of controversy, the dispute usually has focused not on whether disclosure can properly be used as a regulator but on whether the information to be disclosed is material to decisions of legitimate concern to the Commission-those involving purchase, sale, and voting of securities. ${ }^{19}$ The Commission has declined to use disclosure to pursue social objectives, such as environmental protection, where it has not viewed the information involved to be of particular importance to investors. ${ }^{20}$ And while in some cases the SEC has not made clear the primary purpose for which disclosure has been required, ${ }^{21}$ in others it has made clear that disclosure is being required

injury to the plaintiff where the defendants owned sufficient shares to approve the transaction without obtaining any proxies. The court observed that it could not be said that the defendants would have used their power in the same way if they were required to make full disclosure of the facts. In Mills v. Electric Auto Lite, 396 U.S. 375 (1970), the Supreme Court found a causal connection between a misrepresentation in a proxy statement and injury to stockholders based solely on a finding that the misrepresentation was material. Defendants owned more than a majority of the stock but still needed to solicit proxies to gain the requisite votes. Although the reasoning of Justice Harlan proceeds along the same path as Judge Dooling in Laurenzano, the Court did not have to, and did not, embrace Laurenzano and overrule cases to the contrary. 396 U.S. at $385 \mathrm{n} .7$.

19. The use of disclosure as a tool to elevate corporate standards is a legitimate concern of the SEC. William L. Cary, former Chairman of the SEC, advocated the use of disclosure for this purpose. See Cary, Corporate Standards and Legal Rules, 50 CAL. L. Rev. 408, 411 (1962) ("In other words, disclosure restrains because of sensitivity to public reaction, caution about response to the 'dissident' shareholder, and the possibility of legal action.") The SEC confirmed this view in its response to the report of the Advisory Committee on Corporate Disclosure. SEC Securities Act Release No. 33-5906 (Feb. 15, 1978), [Current] Fed. SEC. L. Rev. (CCH) ๆ 81,505, at 80,047-48.

20. Scholars have urged the Commission to use its disclosure powers to pursue social objectives, such as environmental protection. See, e.g., Schoenbaum, The Relationship Between Corporate Disclosure and Corporate Responsibility, 40 Fordham L. Rev. 565 (1972); Branson, Progress in the Art of Social Accounting and Other Arguments for Disclosure on Corporate Social Responsibility, 29 VAND. L. Rev. 529 (1976); Sonde and Pitt, Utilizing the Federal Securities Laws to "Clear the Air! Clean the Sky! Wash the Wind!, 16 How. L.J. 831 (1971).

The Commission has been wary about using disclosure for such purposes, however, and has somewhat casually refused to adopt rules in the environmental protection area. Judge Richey, however, ordered the Commission to hold hearings or make more careful findings in this area. See Natural Resources Defense Council v. SEC, 389 F. Supp. 689 (D.D.C. 1974). After lengthy hearings, the Commission proposed modest rules, $40 \mathrm{Fed}$. Reg. 51,656 (1975), which it modified still further in the final version. 41 Fed. Reg. 21,632 (1976). On appeal, Judge Richey held that the Commission's refusal to adopt rules was arbitrary and capricious and remanded the matter for further consideration. Natural Resources Defense Counsel v. SEC, 432 F. Supp. 1190 (D.D.C. 1977). An appeal has been taken by the Commission.

21. A concern for the public interest is too broad to sustain the Commission's interest. See NAACP v. FPC, 425 U.S. 662 (1976). 
primarily to influence corporate behavior. ${ }^{22}$ When it has used disclosure to promote these regulatory objectives, as in the recent instances where it required disclosure of illegal and questionable payments by corporations, controversy has centered on whether the information was of concern to investors. ${ }^{23}$

We do not conclude from this background that the SEC should adopt disclosure rules that have no potential for informing investors. But the Commission should not shrink from adopting disclosure rules for the explicit purpose of influencing corporate conduct where that conduct is of legitimate concern to the Commission and where the information to be disclosed is relevant to decisionmaking by investors. ${ }^{24}$

\section{B. The Need to Strengthen Boards of Directors}

We turn next to the question whether the SEC should use disclosure for the regulatory purpose of improving the performance of boards of directors of registered companies. This inquiry raises three subsidiary questions: Is there a constructive role in a corporation that can best be played by a board of directors? Can we determine what kinds of boards are capable of playing that role? Are boards now failing to play that role? We conclude that the answer to all three questions is yes, thereby establishing a policy basis for SEC regulatory intervention to strengthen boards of directors.

\section{The Importance of the Board}

We start with the premise that the principal underlying purpose of the securities laws was and is to strengthen the basic institutions of the American

22. Examples of this are disclosure requirements concerning transactions between management and a corporation, see items 11 (a) (promoter's transactions), 17 (remuneration of officers and directors), and 20 (transactions between management and the registrant) of form $S-1$ and item 7 of regulation 14A; disclosure intended to discourage illegal corporate political contributions and other questionable payments, see proposed rule 13b-2 of the Securities Exchange Act of 1934, SEC Securities Exchange Act Release No. 34-13185, 11 SEC Docket No. 8, at 1505 (Jan. 19, 1977) and Release No. 33-5466, 3 SEC Docket No. 18, at 647 (March 8, 1974) (disclosure of illegal political contributions; and disclosure designed to strengthen the position of public accountants in relation to corporate managements, see item 4, form 8-K (change of certifying accountants)), SEC Accounting Series Release No. 165, [1977] FEd. SEC. L. REP. (CCH) ๆ 72, 189.

23. Commissioners have expressed recognition that one of the main accomplishments of the so-called management fraud programs directed against illegal or questionable payments has been to influence corporate conduct. See Truth or Consequences, Address by John Evans, SEC Commissioner, before Securities Cooperative Enforcement Conference, Denver, Colo., at 12 (May 15, 1975); Disclosure and Corporate Management, Address by Ray Garrett, Chairman of the SEC, before the Wharton Graduate Business School Club and Harvard Business School Club, New York, N.Y. (April 14, 1975); Address by Roderick Hills, Chairman of the SEC, before the New York Law Journal, New York, N.Y., at 11, (June 30, 1976); See also Stevenson, The SEC and the New Disclosure, 62 Cornell L. REv. 50, 92 (1976).

24. This view is consistent with the recommendations of the SEC Advisory Committee on Corporate Disclosure. See Digest of Report, 427 SEc. Reg. \& L. REP. (BNA) E-1 and separate statement of Elliott J. Weiss, E-14. (Mr. Weiss was a member of the Advisory Committee.) 
capitalist economic system. Publicly held corporations, probably the most important of those institutions, are strengthened if they operate more efficiently and if those who control them are viewed as doing so legitimately.

Some would argue that market forces and state corporate laws assure the efficiency of corporations and provide them with legitimacy, so that no intervention by the federal government is required. ${ }^{25}$ We dispute those contentions.

Despite the existence of a number of market devices that theoretically promote efficiency, market forces do not adequately control the conduct of corporations. Two principal market regulators are in operation: the capital market, where investors function, and the product market, where consumers function. In the first investors may eliminate inefficiency by causing a change in the control of a corporation or denying it needed capital; in the second inefficiency may be eliminated by business failure. Both reactions are extreme, and both suffer from the defect that substantial slack is tolerated before inefficiency is corrected.

The mechanisms available in the capital market to change corporate control-the takeover bid and the proxy contest-are costly to mount and uncertain of success, especially if management's incompetence is less than total. ${ }^{26}$ In many cases the disciplinary effect of investors' decisions to withhold capital is minimal because the firms can meet their needs with internally generated funds. ${ }^{27}$ Investors also experience great difficulty in using a less drastic remedy-imposing personal liability on management for its failings-because of the broad protection furnished to management by the business-judgment rule.

In the product market the ultimate penalty of insolvency is reserved for the most inefficient firms and imposed only after an extended period of inefficiency. To the extent that an inefficient firm enjoys a monopoly it can escape the control of the product market. Finally, because of the complexity of the corporate structure and the fact that corporate activity is carried out by

25. The view that market forces adequately control the conduct of the corporation is largely premised on the belief that the corporation is a profit maximizer or a profit "satisfier." See Alchian, The Basis of Some Recent Advances in the Theory of Management of the Firm, 14 J. Indus. Econ. 30 (Nov. 1965), reprinted in The Economics of Legal Relationships 487 (H. Manne ed. 1975); Peterson, Corporate Control and Capitalism, Q.J. Econ., Feb. 1965, at 1. See Note, Decisionmaking Models and the Control of Corporate Crime, 85 Y ALE L.J. 1019, 1101 (1976). Substantial doubt about profit maximization as the motivating force behind corporate action is expressed in $\mathrm{J}$. Galbraith, The New Industrial State $166-78$ (1967).

26. Moreover, in recent years the takeover bid has been used more to acquire well-managed companies whose stock is viewed as undervalued. See Metz, Babcock and Wilcox: A Battle that Shook Wall Street Notions, N.Y. Times, Sept. 19, 1977, at 57.

27. Berle, Modern Functions of the Corporate System, 62 Colum. L. Rev. 433, 440 (1962). Following a great rise in the dollar value of securities offered by issuers to the public in the 1960's during the so-called hot issue days, the amount of securities offered by issuers to the public since 1969 has been relatively stable. See [1976] SEC ANN. REP. 42, at 199. 
lower level managers, the signals of the product market may not be transmitted to the senior managers who have the power and responsibility to react to such stimuli. ${ }^{28}$ Since the market does not provide an automatic assurance that corporate goals will be pursued, we conclude that there is a need for organizational strategies directed towards that objective.

One potential role for a board of directors is as a disciplinary force within a corporation. A board, given its legal authority within the firm and its potential access to information and resources, can ride herd on management more effectively than any of the market devices, all of which are external to the firm.

A second potential role for a board is to ensure that management is pursuing a coherent business strategy that is in tune with the corporation's external as well as internal environment. Corporations are made up of people who plan and deal with problems "in the context of an organization chart, a system of measurement and information and a system of managerial reward and punishment that primarily reflects the short-run needs of day-to-day operations."29 This emphasis on short-term results often leads to biases in planning and decisionmaking that are quite harmful to a company. ${ }^{30}$ The possibility of such biases is increased in most large corporations by their divisional organization, which leads to evaluation of managers on the basis of short-run economic and technical results ${ }^{31}$ and to the common modern practice of frequently rotating executives to different jobs, which often increases the importance attached to short-run results. ${ }^{32}$

In addition, management's tendency to measure performance on the basis of short-term, objective standards often leads a firm to ignore the social impact of its operations, which is often difficult to measure. Environmental pollution most readily comes to mind. The corporate decisionmaker's interest in achieving results that best promote his personal goals under the existing reward system often causes the corporation to generate more harmful pollution in order to reduce measurable costs and increase measurable profits. ${ }^{33}$ Thus, as to this facet of corporate performance, market-oriented behavior is counterproductive, encouraging conduct which damages society as a whole. Economist Robin Marris has observed that industrial societies "are increas-

28. C. Stone, Where the Law Ends 201 (1975); P. Drucker, Management: Tasks, Responsibilities, Practices 623 (1974).

29. Bower, On the Amoral Organization, in The Corporate Society 178, 195 (R. Marris ed. 1974).

30. Id.

31. R. Ackerman, The Social Challenge to Business (1975). This leads to the phenomenon described as "subgoal pursuit." O. Williamson, Corporate Control and Business Behavior: An Inquiry into the EFfects of Organization Form on Enterprise Behavior 47-52 (1970). See C. Stone, supra note 28, at 46; $f f$. M. Maccoby, The Gamesman 241-42 (1977).

32. See Bower, supra note 29.

33. Id. 
ingly affected by 'externalities' . . . to such an extent that 'competitive' or market-type systems of socio-economic organization can no longer even approximately tend to optimize social welfare." 34 A board can play an important leadership role in developing and measuring implementation of organizational strategies that will enable a corporation to deal more effectively and responsibly with these problems. ${ }^{35}$

Some might argue that corporate chief executive officers (CEO) should be charged with the task of coordinating and controlling the activities of senior and middle managers to promote the best interests of their firms and that board intervention is not necessary. But frequently the chief executive does not play that role. Studies have found that most CEO's of large firms tend to emphasize short-term goals that "they are single-mindedly, almost slavishly, committed to achieving. ..."36 Thus, it is the board that must counteract this inclination; it best can serve as "a potent force in moderating the management's understandable internal interest in day-to-day achievement." 37

A board also can function to reduce the likelihood of unnecessary errors by a corporation. Economist Kenneth J. Arrow, a Nobel laureate, defines errors as unnecessary "when the information [to deal with a problem] is available somewhere in the organization but not available to or not used by the authority [i.e., management]." ${ }^{38}$ Unnecessary error arises from $^{39}$

overload of the information and decision-making capacity of the authority .... [Moreover, the] efficiency loss due to informational overload is increased by the tendency in that situation [for management] to filter information in accordance with ... [its] preconceptions. It is easier [for management] to understand and accept information congruent with previous beliefs than to overcome cognitive dissonance.

To deal with these problems, which are common to all large organizations, Arrow states that some agency of "responsibility" capable of correcting errors must be created. However, the agency of responsibility should not so limit the discretion of the authority or become so involved in operating decisions that it destroys "the genuine values of authority." 40 Within the corporate context a boardlike entity clearly is best suited to serving the responsibility functions described by Arrow.

Finally, a board can serve to provide legitimacy to a corporation, particularly if it demonstrates that it in fact imposes accountability on management.

\footnotetext{
34. Marris, Conclusion, in R. MARRIs, supra note 29.

35. See Andrews, Can the Best Corporation be Made Moral?, 51 HARv. Bus. Rev., May-June 1973, at $57-64$.

36. Argyris, The CEO's Behavior: Key to Organizational Development, $51 \mathrm{HARV}$. Bus. Rev., March-April 1973, at 55, 57.

37. Andrews, supra note 35.

38. K. Arrow, The Limits of Organization 74 (1974).

39. Id. at 74-5

40. Id. at 79 .
} 
The problem of corporate legitimacy has been discussed in many contexts, but perhaps never so cogently as by Professor Edward S. Mason in his introduction to The Corporation in Modern Society: ${ }^{41}$

[W]e are all aware that we live not only in a corporate society but a society of large corporations. The management-that is, the control-of these corporations is in the hands of, at most, a few thousand men. Who selected these men, if not to rule over us, at least to exercise vast authority, and to whom are they responsible? The answer to the first question is quite clearly: they selected themselves. The answer to the second is, at best, nebulous. This, in a nutshell, constitutes the problem of legitimacy.

\section{A Role for the Board}

Having described functions that can best-or only-be performed by a board of directors does not answer the second of our questions: What kind of board can in fact perform those functions? This question is far from unimportant; one can trace more than forty years of scholarly writing expressing confusion about the proper role of a board and describing the failure of boards to perform various important functions, but not addressing the question of what sort of board could perform them. ${ }^{42}$

But now the situation has changed. A consensus has developed in recent years in support of one model for boards that if adopted could perform the functions we have urged. ${ }^{43}$ The model is of a board with a majority of part-

41. The Corporation in Modern Society 5 (E. Mason ed. 1959).

42. Typical of this body of literature is the observation by Peter Drucker that "In reality the board as conceived by the lawmaker is at best a tired fiction. It is perhaps not too much to say that it has become a shadow king. In most of the large companies, it has in effect been deposed and its place taken by executive management." P. Drucker, The Practice of Management 178 (1954); see also R. Gordon, Business Leadership in the Large Corporation 143-45 (1945).

Naturally, there were numerous proposals for change of the board. Some suggested that the membership be redrawn to include representatives of various constituencies, such as employees, consumers, or social activists, see Interview with Ralph Nader, N.Y. Times, Jan. 24, 1971, \& 3, at 9, col. 2; others suggested the employment of professional directors, see Townsend, Let's Install Public Directors, Bus \& Soc'y Rev. Spring 1972, at 69, a suggestion that had been advanced earlier by Justice Douglas when he was chairman of the SEC, see W. Douglas, Democracy and Finance, 52-3 (1940); others asked boards to professionalize themselves by creating special staffs for outside directors, see Goldberg, Debate on Outside Directors, N.Y. Times, Oct. 20, 1972, § 3, at 1, col 3. See generally The Conference Board, The Board of Directors: New Challenges, New Directions (1972) [hereinafter cited as Conference Board 1972 Report].

43. One can argue, quite convincingly, that until recently the Commission should have declined to impose disclosure requirements relating to boards because neither it nor anyone else had a clear idea of what constituted a properly functioning board of directors. When Congress adopted the securities laws it tacitly adopted the governance scheme of the corporation statutes which provided that "The business of every corporation ... shall be managed by a Board of Directors . ." Gen. Corp. L. OF Del., $\$ 9$ (Ch. 65, 1935 Code). Little attention was paid in the 1930's to what that statutory mandate meant and practically no consideration was given to the board as an institution. See Weinberg, A Corporation Director Looks at His Job, 27 HARV. Bus. Rev. 585,587 (1949). The statutory mandates were apparently relics from the time the prototype corporation was family owned and directors, executives, and principal stockholders were the same. See Douglas, Directors Who Do Not Direct, 47 HARv. L. REv. 1305 (1934).

The position that no one has a clear idea of what constitutes a properly functioning board of directors is untenable today. See notes 42-50 infra and accompanying text. 
time directors who are completely independent of management. ${ }^{44}$ The principal function of this board is not the traditional one of managing the business of the corporation but the more modest, but indispensible, one of monitoring management's performance. ${ }^{45}$

The monitoring function of the board was first stressed by Professor Melvin Aron Eisenberg: ${ }^{46}$

A corporate organ comprised in significant part of nonexecutives can rarely either manage the corporation's business or make business policy. . . There is, however, one cluster of critical functions which such an organ is optimally suited to perform: selecting, monitoring, and removing the members of the chief executive's office. It therefore follows that the primary objective of the legal rules governing the structure of corporate management should be to ensure effective performance of that cluster of functions-if possible, without precluding the board from playing additional roles if it so chooses.

Professor Eisenberg concluded that the "major effect of according the policymaking function central importance, therefore, has been to divert legal and corporate institutions from implementing a function that is both critical and achievable: monitoring." $47 \mathrm{He}$ also stressed that for monitoring to be effective, a majority of a board should be independent of management.

The concept of the monitoring board has received support from many quarters. The Model Business Corporation Act and several state statutes have been amended to provide that "the business and affairs of a corporation shall be managed under the direction of, a board of directors . . ."48 The draftsman of the model act explained in the official comment: ${ }^{49}$

Many commentators have recently voiced concern that [the language requiring that the business be managed by the board of directors] may be interpreted to mean that directors must become involved in the detailed administration of the corporation's affairs. Before the advent of the so-called "outside" director, it was not unreasonable to expect the board to be actively involved in the corporation's business; however, with the development of board participation by individuals not otherwise actively involved with the corporation, any such expectation can no longer be viewed to be reasonable. Indeed, such involvement is clearly neither practical nor feasible insofar as

44. Most observers agree that the board should be composed predominantly of persons who are independent of management. See generally C. Brown, Putting the Corporate Board to WORK (1976) (major theme is independence of the board). Movement in this direction has occurred as most boards are now composed of mainly nonemployees. See J. Bacon, Corporate Directorship Practices: Membership and Committees of the Board 3 (1973). A later study confirms the trend and forecasts its continuation. See Heidrick \& Struggles, Inc., The Changing Board: Profile of the Board of Directors (1977).

45. The board's independence and its monitoring function are closely related: indeed, a board will not succeed in monitoring unless it is independent.

46. Eisenberg, Legal Models of Management Structure in the Modern Corporation: Officers, Directors and Accountants, 63 CALIF. L. REV. 375, 402-3 (1975).

47. Id. at 438 .

48. E.g., ABA-Ali Model Bus. Corp. Act $\$ 35$ (Supp. 1977).

49. ABA Comm. on Corp. Laws, Changes in the Model Business Corporation Act, 30 Bus. LAW. 501, 504-5 (1975). 
today's complex corporation, other than perhaps the closely-held corporation, is concerned . . . . To adapt to current corporate life the revision provides that the business and affairs of a corporation shall be managed under the direction of a board of directors.

A special subcommittee of the American Bar Association's Committee on Corporate Laws, which issued a Corporate Director's Guidebook in November, $1976,{ }^{50}$ interpreted the Model Business Corporation Act as placing responsibility on directors to establish basic corporate objectives, to select senior executives, to ensure the recruitment of competent managers, and to monitor the performance of the enterprise and its managers. ${ }^{51}$ The subcommittee also recommended that a majority of a board be persons independent of management in order to ensure the integrity of the monitoring function. ${ }^{52}$

Professors Noyes E. Leech and Robert H. Mundheim, in an extensive study of outside directors' responsibilities, agreed that monitoring was the central role for outside directors and suggested that statutory requirements for mutual fund directors provide a model..$^{53}$ In enacting the Investment Company Act of $1940^{54}$ Congress decided that stockholders could be protected by independent directors who would monitor the relationship between a fund and its management. ${ }^{55}$

50. Subcomm. on Functions \& Responsibilities of Directors of the A.B.A. Comm. on Corporate Laws, Section of Corporation, Banking \& Business Law, Corporate Director's Guidebook, 32 Bus. LAw. 5 (1975) [hereinafter cited as Corporate Director's Guidebook].

51. Id. at 20 .

52. Id. at 33-35. Another ABA group, The Committee on Corporate Law Departments (composed entirely of inside corporate counsel) has attacked almost every major recommendation of the subcommittee. Report of the Committee on Corporate Law Departments On Corporate Directors Guidebook, 32 Bus. LAw. 1841 (1977) [hereinafter cited as Guidebook Report]. They contend that the recommendations are not required by law and they conflict with sound policy, at least as a universal model. Insofar as the Law Department Committee opposes recommendations favoring a majority of independent directors, and audit and nominating committees composed only of independent directors, it seems to be fighting a distinctly rear guard resistance against a developing trend. The Law Department Committee does correctly point out that the Guidebook is not an official ABA statement and, true to its title, it is a guidebook, not a model statute.

53. Leech \& Mundheim, The Outside Director of the Publicly Held Corporation, 31 Bus. LAw. 1799,1804 (1976).

54. Conflicts of interest were inherent in the mutual fund industry when Congress adopted the Act. Funds were managed by outside companies that contracted with the fund, acting through its board of directors, to provide investment advisory services. The selection of the investment advisor and the determination of the fee were self-dealing transactions that could neglect the stockholders' interests.

55. Nutt, A Study of Mutual Fund Independent Directors, 120 U. PA. L. REv. 179, $182-3$ (1971). The Act sought to achieve these objectives by requiring that at least forty per cent of the board consist of persons who are neither officers nor employees of the fund and who are "unaffiliated" with its investment advisors. Investment Co. Act of $1940, \S 10$ (a) (codified at 15 U.S.C. $\S 80 \mathrm{a}-10$ (a) (1970)). The SEC concluded in its 1966 mutual fund report, however, that unaffiliated directors, particularly as defined in the statute, had failed to provide the necessary protection for stockholders. The Congressional solution was to substitute the broader notion of "interested person" for the narrower definition of "affiliated persons." "Interested person" is defined in the statute so as to exclude from the category of independent directors more than just officers, directors, five-per-cent stockholders, and controlling persons. Those persons are defined 
The courts have given emphasis to these objectives. Management has been held to have violated its fiduciary duty to stockholders by not informing disinterested directors of an opportunity to reduce advisory fees. ${ }^{56}$ The decision of independent directors concerning an advisory contract and management fee has been accorded the benefits of the business-judgment rule, but only when it was a fully informed exercise of judgment. ${ }^{57}$ Independent directors may not escape liability just because they relied on opinions of counsel if that reliance appears to be unjustified under all the circumstances. ${ }^{58}$

While the analogy between the boards of mutual funds and those of other publicly held companies cannot be drawn too closely, ${ }^{59}$ the mutual fund experience demonstrates an acceptance of the monitoring function by independent directors. Moreover, judicial experience under the Investment Company Act indicates that the courts are able to work with the concept of a monitoring board.

The SEC, too, has demonstrated its support for the concept of the independent monitoring board, though the Commission has demonstrated less concern for the contribution a board might make to the efficiency of management than for the way in which such a board can enhance corporate compliance with the reporting and disclosure requirements of the federal securities laws. ${ }^{60}$

as affiliated and, consequently, interested. But, "interested" also includes their close relatives, lawyers for the fund, broker-dealers, and persons whom the Commission shall have determined to be interested by reason of having had a material business or professional relationship with the fund and certain other persons. Section 2(a)(19) defines "interested person" and the concept is carried into $\$ \$ 10(\mathrm{a})$ and $15(\mathrm{c})$ of the Act.

56. Moses v. Burgin, 445 F.2d 369 (1st Cir.), cert. denied, 404 U.S. 994 (1971); Fogel v. Chestnutt, 533 F.2d 731 (2d Cir. 1975), cert. denied, 429 U.S. 824 (1976).

57. Tannenbaum v. Zeller, 552 F.2d 402 (2d Cir. 1977).

58. Papilsky v. Berndt, [1976-77 Binder] Fed. SEC. L. ReP. (CCH) I 95,627 (S.D.N.Y. 1976).

59. This is because there is little else except monitoring that is appropriate or necessary for outside directors of a mutual fund. Directors of most mutual funds have little to do, as the fund is generally externally managed. Conflicts of interest between management and stockholders almost invariably exist, requiring special attention by outside directors. The business of the fund is not complex and many of the fund's activities are regulated by statute. See generally Mundheim, Some Thoughts on the Duties and Responsibilities of Unaffiliated Directors of Mutual Funds, 115 U. PA. L. REV. 1058 (1967).

60. The SEC's recent expression of interest dates from the bankruptcy of the Penn Central Co. and was followed by a more general interest in the role of directors. See STAFF of THE SEC, The Financial Collapse of the Penn Central Company, Report to the Special Subcomm. on Investigations of the House Comm. on Interstate and Foreign Commerce, 92d Cong., 2d Sess. 152 (Subcomm. Print 1972) (SEC staff finds Penn Central board failed "to effectively monitor management"); Address of G. Bradford Cook, Chairman of the SEC, reprinted as Speech on Director's Responsibilities, [1973 Transfer Binder] FED. SEc. L. REP. (CCH) 79,301 (announces preparation of SEC guidelines on the responsibilities of corporate directors); What the SEC Expects of Corporate Directors, Address by Ray Garrett, Jr., Chairman of the SEC, before the Arthur D. Little Corporate Directors Conference, Wash., D.C. (Dec. 17, 1974) (SEC abandons preparation of guidelines due to inability to specify directors' responsibilities in every possible situation; in a common-law approach, SEC urges director to "do his duty"). 
Roderick M. Hills, while SEC chairman, noted that these are important roles to be played by a monitoring board. He said: ${ }^{61}$

Management is too often complacent, self-perpetuating, and unresponsible. When reported profits decline to such an extent as to threaten the serenity of their well paid isolation, some managers are tempted to change the accounting, the figures or the morals of their company in order to present a more pleasing profit picture....

Effective, responsive, and responsible boards of directors will operate to prevent management from going this route, he continued, while boards that are "missing ... a truly independent character that has the practical capacity to monitor and to change management" will not.

Chairman Hills and other members of the SEC have stressed that by ensuring the integrity of corporate reports, the board can provide valuable protection for investors. ${ }^{62}$ The Commission, as a body, emphasized this in its Report of Investigation in the Matter of Stirling Homex Corporation Relating to the Activities of the Directors of Stirling Homex Corporation, ${ }^{63}$ where it took to task two outside directors of Stirling Homex for failing to discover that management had been deceiving both them and the investing public. ${ }^{64}$

However, probably the most important assertion of the SEC's views about the importance of boards has been in enforcement proceedings brought by the Commission. ${ }^{65}$ In a wide variety of cases ranging from conventional failures to furnish adequate information to the more celebrated incidents of illegal political contributions and foreign payoffs, the Commission has perceived that the best remedy to a problem lay in providing for a more effective board. ${ }^{66}$

61. Corporate Rights and Responsibilities: Hearings before the Senate Comm. on Commerce, 94th Cong., 2d Sess. 301-07 (1976) [hereinafter cited as Senate Hearings] (remarks of Roderick M. Hills).

62. An independent board is likely to view ensuring the accuracy of corporate financial reports and other disclosure documents as one of its principal obligations. See Gould v. AmericanHawaiian S.S. Co., 535 F.2d 761 (3rd Cir. 1976); Escott v. Barchris Construction Corp., 283 F. Supp. 643 (S.D.N.Y. 1968).

63. SEC Securities Exchange Act Release No. 11516, [1975-76 Transfer Binder] FEd. SEc. L. REP. (CCH) ๆ 80,219 .

64. The board of Stirling Homex was a particularly passive one. The Commission noted that only seven meetings were held over two years, most of which were perfunctory and several of which were conducted by telephone; that the only committee was an executive committee composed entirely of inside directors, and that no written agenda or memorandums were furnished to assist the board in its functions.

The Commission concluded that the two outside directors "did not provide the shareholders with any significant protection in fact, nor did their presence on the Board have the impact upon the company's operations which shareholders and others might reasonably have expected." Id.

65. The Commission has no power to impose substantive changes in the makeup or operations of the boards of registered corporations. Although the Commission has attempted to make limited changes in registrants' boards by seeking ancillary relief in judicial proceedings, its power in this regard has not been tested judicially. See Comment, Equitable Remedies in SEC Enforcement Actions, 123 U. PA. L. Rev. 1188 (1975); Comment, Court-Appointed Directors: Ancillary Relief in Federal Securities Law Enforcement Actions, 64 GEo. L.J. 737 (1976).

66. In its report to the Senate Banking, Housing and Urban Affairs Committee, the Commis- 
The most important of these actions, in our view, was SEC v. Mattel, Inc., ${ }^{67}$ which involved the filing of false financial statements. The SEC negotiated a consent decree whereby, in effect, it caused a sweeping change in the management of the company. The company agreed to name a majority of unaffiliated directors satisfactory to the SEC, to maintain an executive committee with a majority of unaffiliated directors, to create a financial controls and audit committee and a litigation and claims committee consisting mainly or wholly of unaffiliated directors, and to have special counsel designated by a majority of the new directors. ${ }^{68}$

This was a deep intrusion into corporate governance, with vast potential significance. ${ }^{69}$ The significance of Mattel does not revolve about whether the relief was justified or even whether such sweeping ancillary relief was authorized. It revolves about the SEC's judgment that the way to deal with a problem in the management of a corporation was to create an independent monitoring board, even if this meant that the usual legal procedures under state law for selecting directors were swept aside. Since Mattel the SEC has continued to seek similar remedies for numerous other kinds of management dysfunction ${ }^{70}$ both to correct noncompliance with the law and to reform the

sion observed that "corporate accountability can be strengthened by making the role of the board of directors more meaningful . ..." Commenting on the remedies that had been obtained in the cases, the SEC found "the thoroughness and vigor with which these [audit] committees have conducted their investigations demonstrates the importance of enhancing the role of the board of directors, establishing entirely independent audit committees as permanent, rather than extraordinary, corporate organs and encouraging the Board to rely on independent counsel." SECURITIES and Exchange Commission, Report on Questionable and Illegal Payments and Practices, submitted to the Senate Banking, Housing and Urban Affairs Committee, 94th Cong., 2d Sess. 68 (May 12, 1976); see also Subcomm. on Oversight and Investications, House Interstate and Foreign Commerce Comm., 95th Cong., 2d Sess., Federal Regulation and Regulatory ReForm 34-35 (Comm. print 1976). Private litigation in questionable payment cases has reflected this perception. See, e.g., Gilbar v. Keeler, 75 Civ. Action No. 61 1-EAC (C.D. Cal. 1975) (settlement required majority of "independent outside directors" on the board, its audit committee, and its nominating committee through amendment of bylaws); see also Springer v. Jones, 74 Civ. Action No. 1455-F (C.D. Cal. 1975).

67. [1974-75 Transfer Binder] FED. SEC. L. REP. (CCH) I 94,754 (D.D.C. 1974).

68. See also SEC v. VTR, Inc., [1966] SEC Ans. REP. 32, at 116-17 (S.D.N.Y. 1965) (though SEC sought appointment of receiver, court directs controlling group to elect four independent directors to a five-member board to supervise filing of accurate reports); SEC v. Coastal States Gas Corp., SEC Litigation Release No. 6054 (S.D. Tex.), 2 SEC Docket No. 13, at 451 (Sept. 25, 1973); SEC v. Westgate-California Corp., SEC Litigation Release No. 6142 (S.D. Cal. 1973), 3 SEC DOCKeT No. 1, at 30.

69. Malley, Far-Reaching Equitable Remedies Under The Securities Acts and the Growth of Federal Corporate Law, 17 WM. \& MARY L. REv. 47 (1975); Ruder, Current Problems in Corporate Disclosure, 30 Bus. LaW. 1081, 1084 (1975).

70. SEC v. Allied Chemical Corp., 77 Civ. Action No. 0373 (D.D.C. 1977) (company agreed to investigate environmental risk and to take appropriate action based on that investigation); SEC v. Ormand Industries, Inc., 77 Civ. Action No, 0790 (D.D.C. 1977) (settlement required company to appoint three additional directors satisfactory to the SEC, who were unaffiliated with the company and who would remain on the board for three years); SEC v. General Tire \& Rubber Co., 76 Civ. Action No. 0799, (D.D.C. 1976) (company agreed to create a special review committee consisting of five outside directors, with special counsel, to conduct an investigation into unlawful 
structure of the subject companies' boards of directors. ${ }^{71}$

The monitoring board envisioned by Eisenberg, by the ABA subcommittee, by Leech and Mundheim, and by the SEC, we believe, has the potential to fulfill each of the important board functions described above. ${ }^{72}$ Clearly, with its emphasis on monitoring, it would be able to play the disciplinary role. Removed from day-to-day management and from pressures for short-term results, it would be in a better position than management to question whether short-run performance was congruent with long-range corporate goals. Similarly, because the board would be subject to less intense and exhaustive pressures than management, it would be well situated to assist management in dealing with some of the problems of information overload identified by Professor Arrow. Finally, at least to the extent that the board demonstrated its independence from management and its commitment to hold management accountable, the monitoring board could substantially enhance the legitimacy of the corporation.

\section{Are Boards Failing to Act as Independent Monitors?}

We come, then, to our third subsidiary question: Are boards failing to act as independent, effective monitors of management's performance? We believe many corporate boards are not performing in the desired fashion.

As we will point out below, relatively few data exist about what boards actually do, so any conclusion on this point must be somewhat impressionistic. But our conclusion is supported by one of the most thorough field investigations of boards of directors, which was completed by Professor Myles Mace in 1971. In a book provocatively titled Directors: $M y t h$ and Reality, ${ }^{73}$ Professor Mace described a situation in which most directors serve as passive, friendly

political activities and related matters); SEC v. Sanitas Corp., 75 Civ. Action No. 0520 (D.D.C. 1975) (settlement required the company to maintain audit and legal committees, each composed of outside directors, and each with broad powers). See Wall St. J., Aug. 22, 1977, at 8, col. 1 (settlement with Zale Corp. requires extensive board reform).

These enforcement actions represent important substantive intrusions into corporate affairs. See generally Note, Bribes, Kickbacks, and Political Contributions in Foreign Countries-the Nature and Scope of the Securities and Exchange Commission's Power to Regulate and Control American Corporate Behavior, 1976 Wisc. L. Rev. 1231, 1261. But cf. Santa Fe Indus,, Inc. v. Green, 97 S. Ct. 1292 (1977).

71. Two SEC enforcement attorneys have witten that by employing ancillary remedies "the Commission acts as an effective catalyst for corporate reform to a far greater extent than would be possible solely by the use of its own budgetary and manpower resources." Herlihy \& Levine, Corporate Crisis: The Overseas Payment Problem, 8 LAw \& Pol. In INT'L Bus. 547, 581 (1976).

For a civil suit in which the SEC attempted to impose its concept of directors' obligations, see SEC v. Penn Central Co., [1973-74 Transfer Binder] Fed. SEC. L. ReP. (CCH) I 94,527 (E.D. Pa. 1974); Note, Penn Central: A Case Study of Outside Director Responsibility Under the Federal Securities Laws, 45 U. Mo. K.C. L. Rev. 394 (1977). See also SEC v. Shiell, [current] Fed. SEC. L. ReP. (CCH) If 96,190 (N.D. Fla. 1977).

72. See notes 29-4l supra and accompanying text.

73. M. Mace, Directors: Myth and Reality (1971). 
advisors to management but rarely ask penetrating questions or attempt to evaluate management's performance critically. In recent testimony before the SEC Professor Mace indicated that he does not believe the situation has changed dramatically since he completed his study. ${ }^{\mathbf{7 4}}$

Professor Mace's conclusion is supported by other data and other observers. In many recent cases involving so-called unusual corporate payments, for example, it has been clear that the boards of directors of the companies that made those payments were completely unaware of the questionable means being used to facilitate a large portion of the companies' business. ${ }^{75}$ Surveys conducted by management consulting firms and by the Conference Board indicate that there is a remarkable diversity in how boards conceive of their roles and carry out their functions, with some substantial proportion of all boards operating rather ineffectively.

Thus, in our view, there is no doubt but that there is a widespread failure of boards to function as independent monitors of management performance. Constructive intervention by the SEC could lead to a marked improvement in the effectiveness of many corporations' boards of directors.

\section{The Importance of Information About Boards}

As we noted above, it is generally agreed that before the SEC can adopt disclosure requirements designed to influence corporate conduct it must determine that the information to be disclosed is of material importance to investors. ${ }^{76}$ Disclosure requirements intended to promote more effective boards of directors will cause corporations to reveal information that should allow investors to determine what role a board plays within a corporation. That information, in our view, is material to both investment and corporate suffrage decisionmaking.

\section{Investment Decisions}

Information about the operations of a board is important to investors because the effectiveness of the board of directors can be an important element in an assessment of the quality of management of a corporation, and quality of management is a key element in investment decisions. ${ }^{77}$

74. SEC Hearings on Corporate Suffrage, Washington, D.C., (Sept. 30, 1977) (statement of M. L. Mace).

75. Securities and Exchange Commission, supra note 66, at 93-112.

76. In making that determination, though, the Commission can use its expertise to decide what information should be important to investors, as well as reviewing what information investors say is important to them. See SEC Advisory Comm. on Corporate Disclosure, Report to the Securities and Exchange Commission, submitted to the House Comm. on Interstate and Foreign Commerce, 95th Cong., 1st Sess., Chap. VIII (Comm. Print 1977).

77. A recent survey of individual investors' use of information, conducted by the SEC, found that information about the quality of a company's management was rated "extremely useful" by more respondents $(54 \%)$ than any data except the future economic outlook of the industry of 
The Commission acknowledged this point explicitly in Matter of Franchard Corporation, ${ }^{78}$ where it stated: ${ }^{79}$

Evaluation of the quality of management-to whatever extent it is possible-is an essential ingredient of informed investment decision. A need so important cannot be ignored, and in a variety of ways the disclosure requirements of the Securities Act furnish factual information to fill this need.

However, at the time of Franchard and today the disclosure requirements of the Securities Act and the Exchange Act did not and do not provide investors with nearly enough information to assess the performance of individual directors or the role played by the board within a corporation.

\section{Voting Decisions}

Information that will allow shareholders to assess the performance of individual directors and of the board as a group is also material to shareholders' voting decisions. In fact, it seems likely that the SEC, by its failure to require more meaningful disclosure about boards of directors, has undermined the concept of fair corporate suffrage that the 1934 Act was designed to promote.

The contribution corporate suffrage (in the sense described by Professor Ripley) can make to the efficient operation of a corporation, and the manner in which the SEC's inadequate disclosure requirements have undermined corporate suffrage, are best understood through the work of Professor Albert O. Hirschman, an economist. In Exit, Voice and Loyalty ${ }^{80}$ Professor Hirschman points out that when an organization is operating at less than peak efficiency (as almost all large organizations do), some combination of "exit"-selling one's stock-and "voice"-attempting to influence the organization's conduct-probably will lead to the greatest possible increase in efficiency. However, Professor Hirschman states, people's willingness to rely on voice depends heavily on their estimates of the prospects for success, and ${ }^{81}$

while exit requires nothing but a clearcut either-or decision, voice is essentially an art constantly evolving in new directions. This situation makes for an important bias in favor of exit when both options are present: customermembers [or stockholders] will ordinarily base their decisions on past experience with the cost and effectiveness of voice even though the possible

\footnotetext{
which the company is a part. (Only $50 \%$ rated financial-statement information extremely useful.) Yet information about the quality of management was said to be inaccessible by more respondents than was any other information, with one third of all those who thought it moderately or very useful characterizing it as inaccessible. SEC Advisory Committee on Corporate DisCLOSURE, supra note 76, Survey of Individual Investor Opinion, Questions 3(a) and (b).

78. 42 S.E.C. 163 (1964) (Commission rejects staff recommendation that disclosure be found defective because it failed to mention inadequacy of board of directors' performance; rejection due to Commission view that such finding would require determination of board's adequacy under state law; decision does not deny investors' interest in obtaining information about board).

79. Id. at 169-71.

80. A. Hirschman, Exit, Voice, and loyalty (1970).

81. Id. at 43 (emphasis in original).
} 
discovery of lower cost and greater effectiveness is of the very essence of voice. The presence of the exit alternative can therefore tend to atrophy the development of the art of voice.

This analysis demonstrates not only why the "Wall Street rule" (vote with management or sell) is a popular choice for investors but also why it is unsatisfactory.$^{82}$ Professor Hirschman's argument supports the notion that voice, that is, stockholder participation, is necessary to the health of a corporation. Exit is a blunt instrument; voice is needed for finely tuned attempts to deal with defects in an organization.

Professor Hirschman's analysis also indicates how the effectiveness of voice is enhanced by an improved disclosure process. Disclosure will lower the costs of attempting to use voice. Since a stockholder in a corporation rarely stands to obtain enough direct benefits from attempts to improve corporate governance to make the endeavor profitable to him, costs are a matter of great concern. ${ }^{83}$ If one makes them low enough, in absolute terms, by ensuring that adequate information is readily available to interested shareholders, reliance on voice-or increased shareholder attention to corporate governance-is likely to increase. ${ }^{84}$

Finally, Professor Hirschman's work makes clear why SEC intervention is needed to facilitate corporate suffrage. Hirschman notes that the management of an organization will try to direct its critics to the pressure mechanism to which it is less sensitive, because "the short-run interest of management in organizations is to increase its own freedom of movement ..."85 In the case of large corporations, management usually is not as sensitive to stock sales by disenchanted stockholders as it is to activism on the part of those stockholders. Consequently, management will encourage use of exit and intervention by some third party will be necessary to encourage a better balance between the use of exit and of voice.

82. In light of Hirschman's analysis of why voice tends to fall into desuetude, it is not surprising that investors in general are not clamoring for changes in the proxy rules to allow for more shareholder participation in corporate affairs. The SEC Advisory Committee on Corporate Disclosure, which surveyed both institutional and individual investors, found little active demand for proxy rule changes. SEC Advisory Committee on Corporate Disclosure, Draft of Final Report, Ch. XXIV, at 27-30 (1977).

83. This is a classic positive externality situation-one in which not enough of a social good (here, improved corporate performance) is produced because no individual who can produce the good can capture more than a small share of the benefits from his action. See A. Alchian \& W. Allen, Exchange and Production: Theory in Use 249-50 (1969).

84. The experience of institutional investors who used the services of the Investor Responsibility Research Center (IRRC) is illustrative. The cost to each institution of learning enough about social issues affecting portfolio corporations was high enough to deter them from dealing with those issues. But when IRRC began to make that information available at a much lower cost to each institution, many of them found that the cost of becoming an active shareholder was low enough to warrant pursuing that course of action. See Schwartz \& Weiss, An Assessment of the SEC Shareholder Proposal Rule, 65 GEo. L.J. 635, 648 (1977).

85. See A. Hirschman, supra note 75 , at 123 . 


\section{The Case for a Disclosure Approach}

While the SEC has relied heavily on the concept of the monitoring board in its enforcement program, it has made little use of its disclosure authority either to encourage the development of independent monitoring boards or to elicit information about boards that is of considerable importance to investors. We have outlined above the reasons why the Commission should seek to attain both of these objectives. We elaborate here our reasons for believing that disclosure is particularly well suited to achieving these goals. It is time, we believe, to move from the pathological remedy of enforcement proceedings to the prescriptive treatment of improved disclosure.

\section{Current Disclosure Requirements}

The SEC currently requires disclosure of relatively little information about corporations' boards of directors. Its initial proxy rules, adopted in $1935,{ }^{86}$ called for no information about boards or candidates for election as directors. In 1938, the Commission adopted regulation 14A, the present designation of the proxy rules, requiring information to be sent to stockholders in a proxy statement. ${ }^{87}$ The facts required about directors were sparse: the number of shares in the corporation owned by each director, the relationship of any director with the firm's underwriter, and the identity of any person or body which had nominated a candidate for election to the board.

In the ensuing years, despite periodic revisions of the proxy rules, little additional information has been elicited about boards or individual directors ${ }^{88}$ More information about remuneration of directors, their transactions with the issuer, and their prior experience has been demanded, but most of the data sought is rudimentary and relates primarily to conflicts of interest.

The Commission now has pending a rule change, proposed on November 2,1976 , to require some additional disclosure about directors and candidates for election as directors, including information about their membership on board committees, other directorships held, family relationships with other directors and officers, and whether the director or candidate is subject to

86. SEC Securities Exchange Act Release No. 34-378, (Sept. 24, 1935).

87. SEC Securities Exchange Act Release No. 34-1823, (Aug. 11, 1938).

88. Subject to limitations of the First Amendment, which extend to some aspects of commercial speech, see Virginia State Bd. of Pharmacy v. Virginia Citizens Consumer Council, 425 U.S. 748 (1976), the Commission's authority to adopt rules under 14(a) is quite broad. It is not even limited to ensuring full disclosure. 2 L. Loss, Securities Regulation 868 (2d ed. 1961). When the stockholder proposal rule was adopted in 1942, the reaction on the part of a few members of Congress was so hostile that it provoked the introductions of bills to suspend their effectiveness. Hearings were held, but no action resulted. Hearings on H.R. 1493, H.R. 1821, and H.R. 2019 Before the House Comm. on Interstate and Foreign Commerce, 78th Cong., 1st Sess. (1943) [hereinafter cited as House Hearings]. 
certain kinds of injunctions. ${ }^{89}$ The purpose of the amendments, according to the Commission, is to provide more meaningful disclosure about management. However, the proposal adds no information to the proxy statement about the functions of the board as a body and little about individual directors' activities on the board.

In April 1977 the Commission acknowledged its inaction in this area in a release announcing its first broad reexamination of the proxy rules since 1942.90 The Commission's action appears to have been stimulated in part by controversy about its shareholder proposal rule ${ }^{91}$ and in part by the work of its Advisory Committee on Corporate Disclosure. The Advisory Committee recommended that the SEC adopt "a package of disclosure requirements that, taken as a whole, will strengthen the ability of boards of directors to operate as independent effective monitors of management performance and will provide investors with a reasonable understanding of the organization and role of the board of any given issuer." 92

It would be both desirable and appropriate for the Commission to use its disclosure authority for the purpose of strengthening reporting companies' boards of directors.

Moreover, disclosure is preferable to the obvious alternative-establishment of substantive rules governing the composition and organization of boards of directors. ${ }^{93}$ In light of the amount of experimentation and

89. SEC Securities Exchange Act Release No. 34-12946, [1976-77 Transfer Binder] Fed. SEC. L. REP. (CCH) I 80,783 (Nov. 2, 1976). The SEC's failure to meaningfully amend its proxy rules runs the risk of contributing to what Professor Eisenberg calls the "quack-cure problem," which he describes as "the danger that belief in the validity of the received legal model [of a board that selects officers, sets policy, and generally manages the corporation's business] will forestall meaningful regulation by lulling shareholders, legislators, and the public into the illusion (which often seems deliberately conjured-up) that a disinterested board is supervising the corporation's affairs." Eisenberg, supra note 46 , at 384 .

90. SEC Securities Exchange Act, Release No. 34-13482, 12 SEC Docket No. 2, at 239 (April $28,1977)$

91. See Schwartz \& Weiss, supra note 84. The SEC first advanced the stockholder proposal rule in 1942, House Hearings, supra note 88, at 34-36. Providing stockholders with access to proxy statements for nomination of directors has received some scholarly support. Caplin, Shareholder Nominations of Directors: A Program for Fair Corporate Suffrage, 39 VA. L. Rev. 141 (1953); Eisenberg, Access to the Corporate Proxy Machinery, 83 HARv. L. Rev. 1489 (1970); Note, A Proposal for the Designation of Shareholder Nominees for Director in the Corporate Proxy Statement, 74 CoLum. L. REv. 1139 (1974)

92. Minutes of meeting of SEC Advisory Committee on Corporate Disclosure (May 7-8, 1977). The recommendation was adopted by a vote of 8-7.

93. The Commission probably would have to obtain new legislative authority in order to enforce such standards. Cf. Santa Fe Industries v. Green, 430 U.S. 462 (1977). However, there is some Congressional support for having the SEC set substantive standards. In 1976, the investigations Subcommittee of the House Commerce Committee issued a report calling on the SEC to issue rules to assure that (a) a director of a publicly owned corporation receives compensation and independent staff sufficient to perform responsibly his board duties; (b) a majority of the board is independent of senior management and operating executives and from any other conflicts of interests; (c) the board reviews and approves the corporation's code of business conduct 
change occurring in corporate boards at this time, it would seem inadvisable, at least under the prevailing federal system where most substantive power over corporate affairs rests with state law, to lock all corporations into one pattern of organization. ${ }^{94}$

A major benefit of a disclosure approach to regulation is that it allows for a diversity of responses. New disclosure requirements relating to boards of directors should be designed to force all corporations to think through how their boards should be constituted and what roles they should play, but there is no reason to believe that all corporations will arrive at the same answers to these questions. To be sure, corporations will feel pressure to arrive at answers that they can justify in their public statements, and in many instances that pressure will cause change. But at the same time many corporations will find in their particular circumstances reasons to deviate from the model suggested by the disclosure system. Consequently, a desirable diversity of board practices should result. Even those urging more sweeping corporate reform ${ }^{95}$ must admit that this is a sound first step.

II

\section{A New Disclosure System}

\section{A. Criteria for a System}

It is a challenge to formulate disclosure requirements that will promote independent monitoring boards by providing shareholders and investors with information of substantial value. No small number of facts will demonstrate that a corporation has an independent monitoring board. ${ }^{96}$ Indeed, many aspects of a board's role-particularly its relationship with senior management-cannot be quantified.

and system of internal controls; (d) the board's auditing committee has available to it independent expert advisors; and (e) the board has the authority to hire and fire the independent accountant, legal counsel, the general counsel, and senior operating executives. House CommitTeE oN Interstate and Foreign Commerce, 94Th Cong., 2d Sess., supra note 66, at 52.

94. See Senate Hearings, supra note 61, at 221 (remarks of Professor Mundheim) (legislation, which is difficult to rescind, is inappropriate at a time of experimentation); Guidebook Report, supra note 52, at 1843 (variety of corporate governance practices is desirable).

95. Schwartz, A Case for Federal Chartering of Corporations, 31 Bus. Law. 1125 (1976).

96. The converse is not necessarily true. If a corporation's board is made up largely or entirely of inside directors who hold small amounts of stock in the corporation, it would be reasonable to infer that the board is not likely to serve as an effective independent monitor of management's performance. See M. Mace, Directors: Myth and Reality Ch. 6 (1971); J. Bacon \& J. Brown, Corporate Directorship Practices: Role, Selection, and legal Status of the BOARD 67 (1975). Similarly, while information that a board has certain characteristics will not demonstrate dispositively that it is functioning effectively, disclosure that certain characteristics are lacking will give rise to the inference that the board is not playing an effective role. For an amusing, but realistic, illustration of how a $\mathrm{CEO}$ can foster the appearance that he has an effective board while actually emasculating the board, see Lauenstein, Preserving the Impotence of the Board, 55 HaRv. Bus. Rev., July-Aug. 1977, at 36. 
However, as is now widely recognized, the difficulty of quantifying information should not preclude an SEC requirement for its disclosure. ${ }^{97}$ Rather disclosure requirements should be judged by their potential benefits and costs. $^{98}$ The benefits of effective boards have been discussed; the promotion of such boards by means of disclosure requirements could bring these added benefits: Shareholders and investors would better understand whether a corporation has an active, independent monitoring board, which bears on their investment decisions. Secondly, shareholders and investors would have a sound basis for comparing the activities and organization of different corporations' boards and for the use of "voice" to stimulate change where it seems desirable. Thirdly, shareholders could better assess individual candidates in board elections. They could also better analyze specific board recommendations on which they are asked to vote. Finally-and probably most important-all corporations subject to these disclosure requirements would feel pressure to develop independent monitoring boards.

In our view, the Commission can attain these benefits through new disclosure requirements by drawing on the extensive recent literature on the elements of board effectiveness. ${ }^{99}$ At the same time, we recognize the constraints on any SEC effort to mandate new disclosures about registrants' boards.

One such constraint is the need for confidentiality in boardroom deliberations. These deliberations must be confidential if a board is to discuss business freely and affect it significantly. Confidentiality will be particularly important in a board's relationship with its CEO, which may be delicate while the board is first asserting itself but which is crucial to the board's ultimate effectiveness. ${ }^{100}$ A chief executive unaccustomed to supervision may resist the board's attempts to monitor him and may withhold information the board needs. ${ }^{101}$

97. The debate in this area has focused largely on disclosure of information relating to projections of earnings and business plans. See, e.g., Schneider, Nits, Grits and Soft Information in SEC Filings, 121 U. PA. L. Rev. 254 (1972); Kripke, The SEC, The Accountants, Some Myths and Some Realities, 45 N.Y.U. L. Rev. 1151 (1970). The SEC's Advisory Committee on Corporate Disclosure has urged the Commission to amend its rules to facilitate disclosure of considerably more "soft" information, which the Committee has found often is of prime interest to investors. See Memorandum from Mary E. T. Beach, Staff Director, to Members of the Advisory Committee on Corporate Disclosure, Exhibits E-J (May 26, 1977) (on file with the authors) (hereinafter cited as Beach Memo].

98. Beach Memo, supra note 97, Exhibit $C$.

99. The leading works are Eisenberg, supra note 46; Leech \& Mundheim, supra note 53; Corporate Director's Guidebook, supra note 50; and C. Brown, supra note 44.

100. Development of a board that effectively monitors management's performance does not imply either board interference with management or the development of an adversary relationship between the board and management. "[A]ll that the monitoring function implies is a willingness to be vigilant and questioning in an effort to determine what is in the best interests of the corporation." Leech \& Mundheim, supra note 53, at 1805.

101. Robert Haack, former president of the New York Stock Exchange and now a professional director, has commented that "if you, as a chief executive officer, knew about $80 \%$ more than your average director-and in most cases it's $90 \%$-it's very easy-not by any cupidity or any 
Placing such a board in a fishbowl may encourage directors' traditional preference for passivity and the CEO's attempts to retain autonomy. ${ }^{102}$

Another constraint lies in the purpose of disclosure, which is to provide information pertinent to investment or voting decisions. ${ }^{103}$ The disclosure system should not encourage shareholders to second-guess a board's or a management's business judgments. Thus, disclosure requirements should focus on a board's organization and procedures rather than the substance of its decisions.

In addition, disclosure requirements should not drown shareholders in a sea of minutiae. As a committee of the American Bar Association recently noted, requiring more disclosure in proxy materials can be "a matter of diminishing returns. It is not only that the marginally useful disclosure items will not be read, but they obscure and detract from those that are useful."104 Disclosure requirements should therefore be limited to crucial items. If the disclosure system is successful, it will encourage shareholders to interest themselves in corporate governance and thus to seek out the additional details. ${ }^{105}$

A final constraint is that the Commission should require the disclosure of meaningful information rather than empty jargon. Because some significant information about boards is difficult to quantify, corporations may tend to respond to disclosure requirements with "boilerplate"-formulaic statements that convey little useful information and are drafted primarily to avoid liability for misrepresentation. The Commission can discourage this in public and private; corporations and their counsel are not oblivious to this kind of exhortation. ${ }^{106}$ Furthermore, the factors that have led to past reliance on boiler-

deviousness, but by sheer emphasis or de-emphasis of a point-to persuade a board to your point of view." Corporate Boards of Directors: A Time for Change?, Transcript, Investor Responsibility Research Center Conference (May 31-June 1, 1974) at 70. [hereinafter cited as IRRC Transscript].

102. See Investor Responsibility Research Center, Inc., Shareholders, The Board of Directors and Corporate Governance: Occidental Petroleum Corp., Analysis No. 3, Supp. No. 5, at 3-45, 3-49 (1975) (statement of Paul C. Hebner, vice president, secretary, and board member of Occidental Petroleum Corp.) (board discussions productive only if confidential).

103. SEC Securities Act Release No. 5627, 8 SEC Docket No. 2, at 20, 41 (Oct. 14, 1975).

104. Letter from Kenneth J. Bialkin, Chairman, Committee on Federal Regulation of Securities, American Bar Association, to George A. Fitzsimmons, Secretary, SEC (Dec. 14, 1976) (SEC Public File No. 57-658).

105. Shareholders wishing to suggest changes in board procedures would probably be able to put their proposals in a form that could be voted on by all shareholders, using the procedure set out in rule 14a-8 of the Securities Exchange Act of 1934. For a discussion of how shareholders can make use of those procedures, see Schwartz \& Weiss, supra note 84, at 635.

106. Several factors lie behind our judgment that the prognosis for a constructive corporate response to the proposed disclosure requirements is good. The corporate community is under widespread attack in the United States, and many of its critics focus on the lack of an independent board as one of the factors that undermines the institutional legitimacy of the large, publicly held corporation. See R. Nader, M. Green \& J. Seligman, Constitutionalizing the Corporation: The Case for Federal Chartering of Giant Corporations (1976). The business community is concerned by these attacks. One sign of that concern is the symposium that the Business Roundtable, an association of large corporations, recently sponsored concerning corporate 
plate may not be present in our proposal. In the past the SEC distrusted imprecise and subjective information and conditioned its respondents to provide "hard" data and standard descriptions, no matter how meaningless. ${ }^{107}$ Recently the Commission has modified this distrust and has required or encouraged the disclosure of certain kinds of "soft" information. ${ }^{108}$ Despite the difficulty the SEC has in ensuring the accuracy and adequacy of these data, the results of these efforts have been moderately encouraging. ${ }^{109}$

Fear of civil liability under the SEC's antifraud rules has also encouraged vacuous disclosure in the past. By requiring disclosure of the process and not the substance of decisions, we would abate such fears. It should not require excessive care for corporations to avoid misstatements about board processes. Moreover, in uncontested elections the lack of a causal relationship between misstatements and potential harm would remove virtually all threat of money damages. ${ }^{10}$ The threat of an injunction would remain, but it alone is not likely to lead to timid responses to our proposed disclosure requirements. ${ }^{111}$

boards. Ruder, The Role and Composition of the Board of Directors of a Large Publicly Held Corporation (1977) (report on a symposium of business school deans and others held at the Harvard Business School, May 12-14, 1977) [hereinafter cited as Harvard Symposium]. See also The Business Roundtable, The Role and Composition of the Board of Directors of the Large Publicly Owned Corporation (Jan. 1978).

As Robert M. Estes, former general counsel of General Electric Co., has pointed out, businessmen must build on the differences in the role and responsibilities of the CEO and the directors of a corporation if they "hope to avoid governmental imposition of measures of accountability having a high disaster potential for the viability of the institution." Estes, The Case for Counsel to Outside Directors, 54 Harv. Bus. Rev., July-Aug. 1976, at 125, 127. The proposed rules, we believe, will provide concerned corporations and boards with a framework within which to highlight steps they have taken to enhance the legitimacy of the board and of our current system of corporate governance. Participants in The Business Roundtable's symposium noted that by demonstrating the board's independence and its ability to provide meaningful scrutiny of corporate internal affairs, some of the criticism of corporate operations may be met. Harvard Symposium, supra at 16.

107. See Schneider, supra note 97; Kripke, A Search For a Meaningful Securities Disclosure Policy, 31 Bus. Law. 293 (1975). Among the sections of the registration statement that have been most susceptible to meaningless disclosures are the description of business (item 9 of Form S-1), particularly the part dealing with a description of competition, and the description of litigation (item 12 of Form S-1). The Commission attempted to cure that defect when it amended the guides for preparing a registration statement in 1972. See New Appraches to Disclosure in Registered Security Offerings, 28 Bus. LAw. 505, 522 (1973) (remarks of Warren Grienenberger). See also 160 SEC. REG. \& L. REP. (BNA) A-3 (1972) (remarks of former SEC Chairman William Casey).

108. The Commission has revised rule 14(a)-9, 17 C.F.R. $\$ 240,14(\mathrm{a})-9$ (1977), to delete its prohibition on dividend projections. See SEC Securities Act Release No. 5699, 9 SEC Docket No. 10, at 471 (Apr. 23, 1976); Gerstle v. Gamble-Skogmo, Inc., 478 F.2d 1281 (2d Cir. 1973).

109. The diversity of corporate responses to the requirements of Guide 22 , which requires a management discussion and analysis of the summary of operations, illustrates this point very well. See H. Goodman \& L. Lorensen, Illustrations of the Summary of Operations and Related Management Discussion and Analysis (1975); SEC Advisory Committee on Corporate Disclosure, Minutes of Meeting of Feb. 7-8, 1977, at 5 (on file with the authors).

110. Sisters of the Precious Blood Inc. v. Bristol-Myers Co., 431 F. Supp. 385 (S.D.N.Y. 1977); Lewis v. Elam, [current] FED. SEC. L. REP. (CCH) 96,013 (S.D.N.Y. 1977); Levy v. Johnson, [1976-77 Transfer Binder] FED. SEC. L. ReP. (CCH) I 95,899 (S.D.N.Y. 1977); Cf. Mills v. Electric Auto Lite Co., 552 F.2d 1239 (7th Cir. 1977).

111. Rafal v. Geneen, [1972] Fed. Sec. L. RE.P. (CCH) I 93,505 (E.D. Pa.). 


\section{B. Proposed Disclosure Requirements}

Set out below is proposed language for a set of additional SEC disclosure requirements relating to elections of directors. While each requirement is designed to reveal information of particular significance, the individual requirements are not designed to be evaluated in isolation. Rather it is our intent that they be judged on whether they will contribute meaningful pieces to a mosaic that, taken as a whole, will provide shareholders and investors with a reasonable picture of the role the board of directors is playing within a corporation.

We propose that proxy statements issued prior to shareholders' meetings at which directors are to be elected be required to disclose:

\section{Information About Individual Nominees}

a. Identification of each nominee (and each other person whose term of office as a director will continue after the election meeting) as a management, affiliated nonmanagement, or unaffiliated nonmanagement director and for each affiliated nonmanagement director, a statement of the significant relationship with management that has caused him to be classified as affiliated.

b. The amount of director's fees paid to each nonmanagement director during the previous fiscal year, including separate statements of annual fees, meeting attendance fees, committee membership fees, and committee meeting attendance fees.

c. A tabulation of the number of board and committee meetings held during the previous fiscal year, the total amount of time the board and each committee was in session, and for each board member, the number of board and committee meetings he attended and the total amount of time he spent at board meetings and at meetings of each committee of which he was a member.

d. A list of all other registrants on whose board each nominee serves.

\section{Information About Nominating Procedures}

a. A brief description of the procedures used to select new nominees for election as directors and to determine whether to renominate sitting directors.

b. A brief description of the criteria used to select new nominees for election as directors and to determine whether to renominate sitting directors.

c. A statement whether the registrant's proxy materials have been reviewed and approved by the board of directors (or a committee of the board) prior to their distribution to stockholders and whether the board of directors (or a committee of the board) must specifically authorize or 
approve all expenditures in connection with management's proxy solicitation.

\section{Information About the Organization and Activities of the Board}

a. A brief description of the authority and responsibilities of each standing committee of the board, including information about the frequency with which and the procedure by which each committee reports to the full board and the procedures used for selecting the members of each committee.

b. A statement:

i. Whether board members regularly receive an agenda at least fortyeight hours in advance of meetings of the board and of committees of which they are members, including all documentary materials they need to consider matters proposed by management for approval at the meeting; and

ii. Whether the board or any committee took action on any matters during the previous fiscal year without benefit of such advance information and, if the matters involved material transactions, what the transactions were and what actions the board took.

c. A brief description of the procedures and objective criteria, if any, used by the board to monitor or evaluate the performance of management during the previous fiscal year.

d. A description of any staff assistance furnished to the directors.

\section{Information About Resignation of Directors}

a. A list of all directors who have resigned since the last annual meeting or are not standing for reelection, and a brief statement of the reason why each resigned or is not standing for reelection. The statement either should describe any factors in the operations of the corporation or the organization or activities of its board of directors that bore a significant relationship to the director's decision to resign or not stand for reelection, or should note that there were no such factors.

b. A statement that each retiring director has reviewed and approved as accurate the statement described above, or a description of such factors prepared by each retiring director (which management, in its discretion, may limit to 300 words).

\section{Explanation of Proposed Requirements}

1. Information About Nominees

Directors are elected as individuals, not as a group. ${ }^{112}$ Information about

112. In the 1976 proxy statement of Mobil Oil Corp. stockholders were furnished an oppor- 
individual nominees may be relevant to shareholders' decisions to vote for or against them. It can also contribute significantly to shareholders' and investors' understanding of the role the board and each of its committees plays within a corporation.

Registrants now are required to furnish certain basic data about nominees and directors under item 6 of schedule 14A, and many registrants supplement the required disclosures with various additional information such as a list of additional directorships. Our reasons for adding to these requirements are as follows.

\section{a. Affiliations}

Probably the most important information about each nominee and director concerns his relationship with the management of the corporation. Such information is widely regarded as highly relevant to assessing the probable independence of individual directors from management, and thus of the board as a whole and of each committee of the board. ${ }^{13}$

Many believe that directors who are officers or employees of a corporation cannot be expected to monitor management, ${ }^{114}$ though some would argue that this is not always the case. ${ }^{15}$ In any event it seems sensible to identify clearly directors who are a part of management and what portion of the board they constitute. We would classify as management directors all directors

tunity to indicate from which candidates, if any, stockholders wanted to withhold proxies. The fact that directors are individually elected is at the heart of the suggestion that stockholders have the opportunity to include their nominees in the corporation's proxy statement. See Note, A Proposal for the Designation of Shareholder Nominees for Director in the Corporate Proxy Statement, 74 Colum. L. Rev. 1139 (1974).

113. The classification terms we suggest are drawn from the Corporate Directors Guidebook, supra note 50, at 31. The Guidebook notes that "the terms 'affiliate' and 'affiliated directors' have special meanings, not applicable here, for purposes of the federal securities laws." We attach the same caveat to our use of those terms.

We envision a proxy statement in which the directors in each of the three categories are listed under the appropriate heading, to present most clearly how the board is divided among those groupings.

114. See Eisenberg, supra note 46, at 404-409; sources cited in note 96 , supra. A professional director has commented that "it's difficult to generate any wild enthusiasm among the inside board members over challenging a proposal which has just been advanced by the man who pays your salary." Investor Responsibility Research Center, Inc., Changes in the Corporate Board Room: What Should be Done? Who Should Do It? 35 (1974) [hereinafter cited as IRRC Report] (quoting John A. Patton).

115. One argument sometimes advanced is that employee-directors can be very effective if their principal economic stake in the company is as shareholders, rather than as employees. Investor Responsibility Research Center, Inc., Corporations and the Political Process: Ashland Oil Co., Analysis No. 1, Supp. No. 5, at 1-68 (1975) (quoting Orin E. Atkins, CEO of Ashland Oil Co.).

On the other hand, some of the arguments for electing insiders to the board partake of a certain Alice-in-Wonderland character. For example, Bacon and Brown cite one CEO who argued that a chief executive's tendency to misrepresent the company's performance, though not inhibited by one insider on the board, would be inhibited by two. J. BACON \& J. BROWN, supra note 96 , at $64-65$. 
whose current principal employment is as officers or employees of the corporation, one of its subsidiaries, or any corporation controlled by it or under common control; and all directors who have retired within the past ten years from full-time employment with the reporting corporation, one of its subsidiaries, or any corporation controlled by it or under common control. ${ }^{116}$

Opinion is divided about whether nonemployees who have professional, business, or familial relationships with the management of a corporation - such as outside counsel, investment bankers, commercial bankers, or officers of major suppliers or customers-can be counted on to use their position on a board primarily to promote the interests of shareholders. The leading commentators argue that a relationship of this kind may cause a director to defer to management or to use his position on the board to promote his personal interests even when they conflict with the interests of the corporation. ${ }^{17}$ Another view, advanced most often by persons who are associated with the management of corporations they serve as directors, is that persons with business or professional relationships with a corporation are particularly knowledgable about the affairs of the corporation, and the board should not be denied the benefits of their expertise. ${ }^{18}$

The Fifty-Second American Assembly recently recommended that at least a majority of a board of directors be outside directors, and stated that "family ties, business or other professional arrangements may not disqualify one from serving as a director, but such an individual cannot be held out as an 'outside director' and the appropriate public documents should so indicate."119 We agree. Requiring the identification of such persons as affiliated directors and identifying their exact affiliation will not remove them from the boards of corporations, though it may create a pressure on boards to reduce their number. ${ }^{120}$

116. Corporate Director's Guidebook, supra note 50, at 31. This definition would include within the category of management director, retired operating executives who now devote substantial amounts of time to their responsibilities as directors. Among major corporations, Texas Instruments, Inc., Connecticut General Insurance Corp., and Westinghouse Electric Co. have such directors on their boards. See J. BACON \& J. Brown, supra note 96, at 36-39; Board Power, 118 Forbes 47 (July 1, 1976).

117. See Eisenberg, supra note 46, at 405-406; Leech \& Mundheim, supra note 53, at 1830-31; M. MACE, supra note 96, at 199-203.

118. See IRRC Report, supra note 114, at 52-54; J. BACON \& J. Brown, supra note 96, at 45-47; Guidebook Report, supra note 52, at 1850.

119. The Ethics of Corporate Conduct, Report of the Fifty-Second American Assembly, Harriman, N.Y., 5 (April 14-17, 1977). The New York Stock Exchange, by way of comparison, abandoned its effort to identify which directors are outside directors for purposes of its requirement that all listed companies have audit committees made up of nonmanagement directors. It left to companies' boards the decision as to which directors are "independent of management and free from any relationship that ... would interefere with the exercise of independent judgment as a committee member," while providing them with some nonbinding guidance concerning factors to be considered in making that determination. New York Stock Exchange, Audit Committee Policy (Jan. 6, 1977).

120. It is difficult to determine, from available data, what proportion of the persons now 
As to what constitutes a significant relationship for this purpose, we recommend that a director be classed as affiliated if (a) he has during the last fiscal year of the corporation engaged in, or proposes in the future to engage in, transactions with the corporation that are material to the corporation, to him, or to a corporation with which he is associated; (b) he has close familial ties to an officer of the corporation; or (c) a director of a corporation of which he is an officer or employee is an officer or employee of the corporation on whose board he serves. An appropriate guide for determining the existence of a material business relationship would be the tests in schedule $14 \mathrm{~A}$ of the proxy rules for required disclosure in a proxy statement of direct or indirect material interest in transactions with the corporation. ${ }^{121}$ Close familial ties should include those who are first cousins or closer and the spouses of all such persons.

To classify the directors chosen by a reciprocal arrangement as affiliated is an expansion of the relationships usually mentioned as likely to influence a director's judgment, but we believe disclosure of this relationship to be pertinent. We are not aware of any survey data on how common such relationships are, but we believe that a substantial portion of all outside directors are involved in reciprocal relationships. How these relationships arise, and how they are apt to warp a director's judgment, have been succinctly described by Marvin Chandler, former CEO of the Northern Illinois Gas Company: ${ }^{122}$

When A serves on B's board, A gets to know B and views him as a fine executive, a compatible person, and an ideal director for A's company. . . .

It is asking too much of A to pull no punches in his director's role at B's company, when he knows that B in turn is appraising his [A's] performance. It becomes almost like, 'You set my salary this week and I'll set your salary next week.'

\section{b. Compensation}

The amount of compensation paid to directors, and the basis on which it is paid, may be significant indicators of the seriousness with which management views the board of directors and the seriousness with which the directors take their responsibilities. As Roderick M. Hills, then chairman of the $\mathrm{SEC}$, remarked, "Compensation for directors of too many large corporations

serving as nonmanagement directors of corporations would be classified as affiliated. Korn/Ferry International found that in 1976, companies had "one or more of the following individuals" (who might be classified as affiliated directors) on their boards:

Senior Executive (other companies) $\quad \mathbf{8 5 . 5 \%}$

Commercial Banker

Attorney (provides legal services to the company)

Korn/Ferry International, Board of Directors: Fourth Annual Study 8-9 (Feb. 1977) [hereinafter cited as Korn/Ferry Survey].

121. Item 7, Schedule 14A.

122. Chandler, It's Time to Clean Up the Boardroom, 53 HARv. Bus. Rev., Sept.-Oct. 1975, at 73. 
is set at a figure which makes it apparent that no real work is expected." ${ }^{23}$ Similarly, Ralph M. Lewis, editor of the Harvard Business Review, has noted that "if a high level of activity is expected of an outside director, he should be well paid. ... [O]utside directors are human, and they tend to view as important those activities for which they are well paid, even if the actual money is inconsequential to them." 124

While the disclosure that directors are paid a pittance may indicate they are not expected to do much, it does not necessarily follow that directors who are well paid can be assumed to be playing an active and effective role. But substantial fees are one indication that a corporation takes its directors seriously..$^{125}$

\section{c. Attendance}

It seems self-evident that whether a director regularly attends board and committee meetings is relevant to an evaluation of his performance. ${ }^{126}$ Indeed, the companies that responded to a recent survey of boards of directors ranked attendance at board meetings as the second most important factor in evaluating directors' performance, with seventy-seven per cent of the respondents listing it as significant. ${ }^{127}$ Thus a strong case exists that such information should be disclosed to the public. ${ }^{128}$

Data on the frequency and duration of board and committee meetings will be valuable in permitting comparison among different corporations. ${ }^{129}$ In ad-

123. Senate Hearings, supra note 61 , at 301 (statement of Roderick M. Hills).

124. Lewis, Choosing and Using Outside Directors, 52 HARv. Bus. REv., July-Aug. 1974, at 70, 72. See also HARVARd Symposium, supra note 106 , at 7 .

Recent surveys indicate corporate directors are paid fees within a wide range, and on the basis of several different compensation arrangements. See Korn/Ferry Survey, supra note 120, at 11-16; Heidrick \& Struggles, Inc., supra note 44; J. Bacon, Corporate Directorship Practices: ComPENSATION (1975).

125. Texas Instruments pays fees to its outside directors based in part on the amount of time they devote to company business, and one commentator has suggested that corporations should generally adopt this practice. Mace, Designing a Plan for the Ideal Board, 54 Harv. Bus. Rev., Nov.-Dec. 1976, at 20,36. [hereinafter cited as Mace, Ideal Board].

General Motors Corp., in the proxy statement for its 1977 annual meeting, described in some detail its compensation plan for directors. General Motors Corp. proxy statement dated May 20, 1977. However, it only published the exact amounts paid to the two outside directors who received more than $\$ 40,000$ in 1976 - the threshhold above which compensation must be reported. See Item 7 of regulation $14 \mathrm{~A}$.

126. " $[\mathrm{I}] \mathrm{t}$ is expected that a non-management director will devote substantial time to the affairs of the corporation. . ." Corporate Director's Guidebook, supra note 50, at 33.

127. Heidrick \& Struggles, Inc., supra note 44, at 12.

128. In the Stirling Homex release, supra note 63 , the Commission noted somewhat disparagingly that the board had met only seven times in two years.

129. For example, one author describes a board with fifteen members, "some of whom spend relatively little time on company problems," and an executive committee made up of the CEO and four outside directors which plays quite an active role in overseeing the affairs of the company and meets much more frequently than does the full board. See Lewis, supra note 124, at 77; Korn/Ferry, supra note 120 , at 19 . The proposed disclosure requirement would provide shareholders with significant indications that a board was so organized. 
dition, it will provide stockholders with an opportunity to determine whether committees have devoted adequate time to their responsibilities. It also will restrain exaggerations about the responsibility that a company may claim the board has exercised. ${ }^{130}$ For example, there is evidence that in the last few years many audit committees substantially increased the time they devoted to reviewing companies' internal controls and financial reports. ${ }^{131}$ Shareholders and investors should be provided with a sound basis for determining whether this trend has occurred at a corporation, or whether the audit committee is merely "spending two to four hours a year in cut-and-dried sessions with a perfunctory look at the figures and the situations raised by the independent auditor's management letter," a level of performance that one professional director has stated "is not my idea of . . the proper discharge of the responsibilities associated with service on an audit committee."132

\section{d. Other Directorships}

To do a conscientious job a director must be able to devote a substantial amount of time to the affairs of a corporation. Information about other directorships, particularly when combined with information about a director's principal occupation and his attendance at board meetings, should provide shareholders with an indication of whether the director is overextended. ${ }^{133}$

\section{Information About Nominating Procedures}

There is a clear nexus between the process by which directors are selected and the likelihood that directors will serve as independent monitors of management's performance. Similarly, the process of selection may have a large bearing on the diversity of a board. The selection process is likely to influence both the kinds of people chosen as directors and the manner in which these people, once chosen, will serve on the board. The salient point to

Korn/Ferry found directors spent an average of 102.5 hours in 1976 on board business, including board and committee meetings and "expected homework."

130. Since the minutes of board and committee meetings usually state the time meetings began and ended and the times directors present for less than the full meeting arrived or left, compiling this data would not be very burdensome. Moreover, the existence of the minutes would serve as a safeguard against puffing of a director's attendance figures.

131. See Mace, From the Boardroom, 53 HARv. Bus. Rev., Sept.-Oct. 1975, at 18, 170-171.

132. Barr, The Role of the Professional Director, 54 HARv. Bus. Rev., May-June 1976, at 18, 24. On the relationship between time commitments and the effectiveness of the audit committee, see generally Lovdal, Making the Audit Committee Work, 55 HARv. Bus. REv., Mar.-Apr. 1977, at 108.

133. The SEC has proposed amending schedule $14 \mathrm{~A}$ to require a listing of all other directorships. SEC Securities Act Release No. 5758, 10 SEC Docket No. 17, at 834 (Nov. 2, 1976). Some argue, though, that requiring disclosure of other directorships would not serve this purpose. The chairman of a large insurance company stated that he and most other outside directors are already seriously overcommitted. Consequently, he said, reducing the number of boards on which he serves would not really allow him to devote much more time to those on which he continued to serve. IRRC Report, supra note 114, at 39-40. 
remember is that nomination as a management candidate is tantamount to election.

In most publicly held corporations, the CEO selects the nonmanagement candidates for election to the board. A recent survey of directorship practices found that the "initial decisionmaker in approving board prospects" was the chief executive officer in 46.5 per cent of the corporations responding, the board as a whole in 24.9 per cent of the companies, the board's executive committee in 15.5 per cent, a board nominating committee in 8.2 per cent, the inside directors in 2.9 per cent, and others in 2.0 per cent. ${ }^{134}$

In selecting outside directors, the CEO faces a conflict of interest. He has a personal interest in avoiding candidates with the characteristics that make effective, independent members of the board. According to one authority: ${ }^{135}$

The typical CEO picks his outside directors with two things in mind:

1. He wants someone with whom he can feel comfortable. He needs no surprises. He feels he has enough problems running his business. The old friend, whose reactions he knows well, with whom he can discuss confidential issues, is a prime candidate. If the CEO moves outside the group he knows personally, the candidate is rigorously investigated, the major questions being 'Is he solid?' and 'Is he sympathetic?'

2. At the same time, the CEO wants someone who will lend prestige to his board.

Similarly a professional director found that in the replies of 160 CEO's to a poll that he conducts about professional directors "there was an undercurrent . . . that could be paraphrased, 'We wish to God that we did not have any outside directors, but especially no professional directors." 136 The author commented that this view appeared to reflect the desire of the managements of many large corporations to reinstate the autocratic management styles used

134. Heidrick \& Struggles, Inc., supra note 44, at 8. See also J. BAcon \& J. Brown, supra note 96 , at 28 (similar conclusions from discussions with CEO's and directors).

135. Lewis, supra note 124, at 71. See also Leech \& Mundheim, supra note 53, at 1826; Cole, New Attention on the Corporate Director, N.Y. Times, Apr. 29, 1977, $\S$ D, at 1.

One authority on boards suggest the following as typical of the way one CEO would invite another to join his board:

George, we have a vacancy on our board, and I would be pleased if you would agree to

join us. You know most of our current board members. You are as busy as everyone else but we meet only once a quarter at lunch, and meetings rarely take more than two hours. You have to eat somewhere and we hope you will accept. I won't burden you with a lot of homework. In fact we don't send out any material prior to meetings. Your point of view as a corporate CEO, a proven generalist, would be most helpful to me.

Mace, Attracting New Directors, 54 Harv. Bus. Rev., Sept.-Oct. 1976, at 46, 48.

It is interesting to note that Heidrick and Struggles found 44.5 per cent of the chairmen surveyed listed the reputation of their company as the most persuasive appeal for attracting directors and 38.4 per cent listed the opportunity to contribute. "In contrast two-thirds of recently elected outside directors surveyed by Heidrick and Struggles in another study report that the opportunity to contribute was the reason they joined boards. Only one fourth were motivated primarily by company reputation." Heidrick \& Struggles, supra note 44, at 8.

136. Barr, supra note 132, at 19. 
by those companies' founders. "[I]t is only natural," he said, "that many managements today must look back with a certain nostalgia to the days of the founder and the inside board."137

The directors selected by a CEO are not likely to bite the hand that picked them. Most of these directors will be chief or senior executives of other business corporations, members of the peer group of the CEO. They usually are busy people, they sense that the CEO is not interested in having an active board, and they behave passively. ${ }^{138}$ Robert M. Estes, former general counsel of General Electric Company, has perceptively noted that the reason "why it's so difficult to arouse outside directors as a class" is that most outside directors are executives of other corporations. The "primary reactions" of such an executive to suggestions that boards be more active, Mr. Estes stated, "will tend to be controlled by his primary role. In terms of the theory and practice of corporate boards, his instinctive concern is the board where he carries the ultimate personal responsibility for the success of the enterprise," not the boards on which he sits as a nonmanagement director. ${ }^{139}$

The disinclination of outside directors selected by the CEO to be assertive is reinforced by the social ethic which dominates most boards' operations. A nonmanagement director of several corporations remarked to one of the authors: ${ }^{140}$

Being invited to sit on a board is just like being invited to join an exclusive private club. In that atmosphere, I wouldn't think of asking the man in charge of [a] division of [the] corporation why his rate of return is half that of the industry average. It just isn't done.

Moreover, the pressures that constrain directors from asking penetrating questions about the performance of division managers operate even more forcefully when it is the chief executive's performance that a board is evaluating. Indeed, as Professor Mace has described, a board made up of directors selected by the CEO is likely to remove him from office only when his "performance becomes so bad that even his mother thinks he has to leave . . ."141

Finally, a nonmanagement director who is inclined to assert himself may hesitate if the chief executive officer retains effective control over the nomina-

137. Id. at 20. See also Groobey, Making the Board of Directors More Effective, 16 CAL. MANAGEMENT ReV., Spring 1974, at 25, 27.

138. IRRC Transcript, supra note 101, at 12-14 (remarks of Myles L. Mace).

139. Estes, supra note 106 , at 127.

140. Clarence Randall, former chairman of Inland Steel, similarly acknowledged businessmen's belief "that criticism from outside is to be expected, but that it should never come from within the lodge itself" (Emphasis added.) C. Randall, The Folklore of Management (1959) quoted in C. Brown, supra note 44, at xxvi. See also Groobey, supra note 137, at 28-29; Lasker v. Burks, 567 F.2d 1208,1212 (1978) ("It is asking too much of human nature to expect that the disinterested director will view with necessary objectivity the actions of colleagues in a situation where an adverse decision would be likely to result in considerable expense and liability for the individuals concerned.")

141. IRRC Transcript, supra note 101, at 9 (remarks of Myles L. Mace). See also McColough, The Corporation and its Obligations, 53 HaRv. Bus. Rev., May-June 1975, at 127, 131-132. 
tion of directors for reelection. A director's “independence may be jeopardized if the board member's compensation is materially important to him and if the management or chief executive officer has (or appears to have) the dominant voice in the renomination of incumbent members." ${ }^{142}$ This problem may be even more acute for the director who depends on management for the maintenance of a material professional or business relationship which might be terminated, together with the director's membership on the board, if the director behaves in a fashion that management decides is too independent. ${ }^{143}$ In sum, if the CEO controls the proxy process, that control will tend to reinforce "his economic and psychological dominance" of board members whom he has selected personally. ${ }^{144}$ It aggravates the situation that outside directors often are chosen exclusively from the business community, which furnishes too narrow a base from which to choose the entire board. ${ }^{145}$

Short of making revolutionary changes in the corporate governance system, ${ }^{146}$ the best alternative to having directors selected by the CEO is to assign the task of selecting and renominating directors to a nominating committee made up of unaffiliated nonmanagement directors. ${ }^{147}$ The Corporate Director's Guidebook states that a nominating committee so constituted "is potentially the most significant channel for improved corporate governance, since over a period of time it can have a marked impact on the composition of the board of directors and the manner in which management succession is effected."148

Professors Leech and Mundheim also assign a crucial role to the nominating committee. They state: ${ }^{149}$

An important step in creating an environment conducive to an independent attitude on the part of outside directors is selection of outside directors by a

142. Leech \& Mundheim, supra note 53, at 1830.

143. Id.

144. Eisenberg, supra note 46 , at 408 .

145. See note 153 infra.

146. Such as having stockholders use the proxy materials to solicit support for their nominees. We do not rule out the wisdom of such changes; we simply do not deal with them in this article.

147. General Motors Corp., among others, has such a nominating committee. See Leech \& Mundheim, supra note 53, at 1807.

148. Corporate Director's Guidebook, supra note 50, at 35.

149. Leech \& Mundheim, supra note 53, at 1830. See also C. Brown, supra note 44, at 48-49; Eisenberg, supra note 46, at 407-408; Transcript, Conference on Federal Chartering of Corporations, American Enterprise Institute, Wash., D.C., 128-29 (June 21, 1976) (remarks of Roderick M. Hills, then Chairman of the SEC); Cf. Mace, John J. McCloy on Corporate Payoffs, 54 HARv. Bus. Rev., July-Aug. 1976, at 14, 159 quoting McCloy:

Professional managers have had too much authority in selecting directors and in determining what their functions are. The selection of new members of the board should not be the prerogative solely of the management. The outside board members already in place should more actively participate in the selection. . . .

The American Assembly recommended establishment of nominating committees with a majority of outside directors "to search for qualified candidates of diverse background for submission to the full board as possible nominees to the board." The Ethics of Corporate Conduct, supra note 119 , at 5 . 
nominating committee composed wholly of outside directors. Although the nominating committee should consult with the chief executive officer about possible board candidates, the committee should not feel bound to adopt management's slate of candidates.

The existence of a nominating committee made up of outside directors is not apt to result in dramatic changes in the membership of a board, but it is likely to increase the director's feeling of loyalty to the board rather than to the CEO. Over time both the new selection process and the resultant feelings of independence are likely to become institutionalized. ${ }^{150}$

The requirements we propose for disclosure about the nominating process aim not only to inform shareholders but to influence the electoral process as well. The latter objective is justified by the SEC's interest in enhancing board independence, which depends upon the selection process. ${ }^{151}$ Disclosure is especially well suited to effect change in this area. Many chief executives are notorious for their consistent claims of obeisance to the interests of their stockholders and the dictates of their boards. Rather than admit publicly that they monitor their own monitors, they are likely to surrender some of their control over nominations. ${ }^{152}$ Disclosure should also affect shareholder participation. With information about nominating procedures and criteria, shareholders will be better equipped to discuss prospective candidates with management or the board. ${ }^{153}$

\section{a. Procedures}

The disclosure of procedures used to select nominees would include a description of who-the CEO, a nominating committee, the full board, or others-is responsible for recommending board prospects; what processes are used to identify and screen prospects; whether the CEO has a right to veto new candidates or nominees for reelection; and whether the board, or any committee of the board, regularly solicits or reviews shareholders' recommendations on changes in board membership. ${ }^{154} \mathrm{~A}$ corporation should also be re-

150. IRRC Report, supra note 114, at 22

151. This point has been made by Professor Alfred Conard, who has argued that directors' liability should be premised principally on their failure "to remove incompetent directors, or . . . to call for investigation of symptoms of malfunction." See Conard, A Behavioral Analysis of Directors' Liability for Negligence, 1972 Duke L.J. 893, 917.

152. See Harvard Symposium, supra note 106 , at 14.

153. For example, when a shareholder group tried to question the chairman of General Motors Corp. about the reasons why two new directors had been added to GM's board, it received responses that added little to its understanding of why those persons had been chosen. See Schwartz, The Public Interest Proxy Contest: Reflections on Campaign GM, 69 Mich. L. REv. 419, 477.78 (1971).

154. The Corporate Director's Guidebook says that a procedure allowing shareholder to make suggestions to a nominating committee will be "a more effective and workable method of affording access to the nominating process to individual shareholders than a direct 'right' of nomination in the corporation's proxy materials." Corporate Director's Guidebook, supra note 50, at 35. 
quired to notify shareholders if these procedures have not been followed with respect to any nominee. ${ }^{155}$

\section{b. Criteria}

The disclosure of criteria for selection of nominees should identify the traits that the person or persons responsible for nominations look for in all candidates and formulae that may be used in order to obtain a desired balance on the board. ${ }^{156}$ For example, a recent survey found seven considerations were listed by at least ten per cent of the respondent companies as relevant to their selection of new directors. ${ }^{157}$ Some corporations clearly prefer a board made up primarily of CEO's of other companies; ${ }^{158}$ in those cases that criterion would be mentioned. Similarly, if a corporation had a policy limiting the number of CEO's on its board, a policy barring all affiliated persons from being directors, a policy limiting the number of management directors, or a policy requiring that a certain proportion of the board be made up of unaffiliated nonmanagement directors, these policies would be disclosed. Armed with this information, shareholders would be in a much better position to suggest nominees to management and to evaluate whether new nominees were qualified in terms of the announced criteria. ${ }^{159}$ If they disagreed with the cor-

155. The notification requirement should promote independence among the directors by making arbitrary action against them more difficult to pursue. See C. Brown, supra note 44 , at 84; Leech \& Mundheim, supra note 53, at 1831 .

156. See Heller, The Board of Directors: Legalistic Anachronism or Vital Force, 14 CAL. MANAGEMENT REv., Spring 1972, at 24, 28:

What steps should a company take to make sure that the proper people are serving on its board of directors? Specific criteria should be developed and tailored to the needs of the individual company. .

Once the specific criteria for a company's board members have been developed and agreed upon, the present composition of the board should be analyzed and evaluated. A program must then be developed to recruit to fill identified needs and to develop a strategy for retiring board members whose future contributions are likely to be limited.

157. The factors and the precentages of companies that considered them in selecting directors were:

Probable ability to contribute

$98.6 \%$

Stature

$52.6 \%$

Functional area represented

$45.5 \%$

Experience as directors

$35.4 \%$

Time availability

$26.9 \%$

Stock ownership

Geographic area represented

$12.3 \%$

$10.0 \%$

Heidrick \& Struggles, supra note 44, at 9. See also J. BACON, supra note 44, at 40-47.

158. See Barr, supra note 132, at 19, commenting on this phenomenon. Another atypical director of several major corporations notes that "an individual who spends his or her life solely in the pursuit of greater corporate efficiency and maximizing the profits of the stockholder is somewhat removed from the day-to-day ferment of political life." Harris, New Constitutencies for the Board in Conference Board 1972 Report, supra note 42. See also Harvard Symposium, supra note 106, at 8; Mace, Ideal Board, supra note 125 , at 30.

159. A few companies have volunteered information about how they select directors. By examining that information, we can gain some insight into what information registrants might make 
poration's criteria, they would also be in a position to make more informed and sophisticated suggestions for altering them.

Requiring disclosure of the criteria for renomination of directors would let stockholders know if a board had some standards or process for evaluating directors' performance. While some of the criteria disclosed, such as the quality of a director's suggestions, might be relatively meaningless, others-such as attendance at board and committee meetings, time devoted to reviewing the company's operations, or specified ages or circumstances for retirementwould be moderately significant to an evaluation of the board's operations and the manner in which it actually applied these criteria to nomination for reelection. The publication of such criteria might also make it easier for the board to rid itself of dead wood without undue embarrassment.

\section{c. Proxy Review}

There is no specific legal requirement that the board of directors review a corporation's proxy materials, and we are not suggesting that the SEC impose such a requirement. However if our other recommendations are adopted, much of a registrant's proxy statements will be devoted to the selection of directors and the organization and operations of the board. It would then be desirable for the SEC to require that shareholders at least be informed whether the board itself had reviewed the proxy materials before they were published.

Finally, requiring disclosure of the manner in which the board exercises control over proxy solicitation expenses will complete the picture of who controls the corporation's participation in the election process. Control of the purse strings is an important part of that process, and information should be

available pursuant to the proposed disclosure requirement and how that information might be used by investors.

The criteria used by Northern Illinois Gas Co. for evaluating a potential nonmanagement director appear in Chandler, supra note 122, at 76. A description of the criteria and process used to select nonemployee directors of Exxon Corp. and how they performed in one instance appears in 2 IRRC News for Investors 100-01 (May 1975). General Motors, in its proxy statement for its 1975 annual meeting, included a discussion of the basis on which it selected directors. As a part of its director selection process, Pullman, Inc., reportedly uses a matrix to analyze the skills needed to perform directorship duties and the skills possessed by its current directors. See Mace, supra note 135 , at 54 .

While a corporation probably would use the same language from year to year to describe its criteria-unless those criteria change-these statements would not be meaningless formulae. Rather they would provide a basis for shareholders to use voice to bring about changes in the criteria. See notes 80 to 85 supra and related text.

By publishing the criteria used to select directors, a corporation also would better inform shareholders when it was undertaking major shifts in the makeup of its board. That rarely is done now. For an example, in the early 1970's Xerox Corp. shifted from a board made up largely of Rochester, N.Y.-based businessmen to one made up of prominent academics and international businessmen, but did not provide shareholders with an explicit statement that it was making such a shift or an explanation as to why it was being made. See Investor Responsibility Research Center, Inc., Shareholder Nomination of Candidates for Director: Xerox Corp., Analysis No. 7, Supp. No. 2 (April 30, 1973). 
made available about how closely the board or any of its committees supervise expenditures for proxy solicitations.

\section{Information About Board Organization and Activities}

Requiring disclosure of how a board is organized and how it has functioned can both influence the board's performance and generate information of considerable importance to shareholders. Information about the organization and activities of directors is highly relevant to board elections, since the vast majority of candidates for election as directors are standing for reelection. Data about the performance of those candidates and the boards on which they have served are likely to be highly relevant to shareholders' voting decisions in cases where there is any choice, as well as relevant to nominations.

It is in the area of board activities, however, that the constraints of confidentiality, of limiting disclosure requirements to matters of legitimate interest to shareholders, and of keeping disclosure within manageable limits all are likely to be most vexing.

In our view, the best approach to balancing these conflicting interests is to be selective in developing disclosure requirements relating to the activities of a board, and to focus those requirements on the processes through which the board operates rather than on the substance of the board's deliberations or decisions. Specifically, the disclosure requirements should focus on the board's committee system, on the flow of information to the board, and on the process by which the board monitors management's performance. Related to these matters is the amount of staff assistance furnished to the board.

\section{a. Committees}

Boards are coming to rely more heavily on committees as a means of carrying out their responsibilities, ${ }^{160}$ and that trend is likely to accelerate if a recent amendment to the American Bar Association's Model Business Corporation Act is adopted widely as part of state corporation laws. The amendment allows a director to rely on information and reports presented by a board committee on which he does not serve if he reasonably believes that the committee deserves his confidence. ${ }^{161}$

160. See IRRC Report, supra note 114, at 15-16 for a description of the committee system developed by the board of General Electric Co.; and $i d$. at 42-44 for a discussion of the pros and cons of increasing use of committees. See Leech \& Mundheim, supra note 53, at 1807-09 for a description of the committee system developed by the board of General Motors Corp. See also Harvard Symposium, supra note 106, at 10; under a recently adopted New York Stock Exchange Rule, by June 30, 1978, all listed companies must have audit committees comprised solely of independent, nonmanagement directors. New York Stock Exchange, supra note 119.

161. ABA-Ali Model. Bus. Corp. ACT \& 35 (Supp. 1977). See also the comment of the ABA Committee on Corporate Laws on this portion of its amendment to the Act in ABA Comm. on Corporate Laws, supra note 49. 
Information about what committees a board has, what their authority and responsibilities are, how they report to the full board, and how committee members are selected can be vital to any appraisal of the role that board plays. ${ }^{162}$ For example, some boards have executive committees that meet much more frequently than the full board, that are authorized to exercise all of the powers of the full board except those reserved to the board by statute, that do not report regularly or in any detail to the full board, and that are made up wholly or primarily of management directors selected by the CEO. Other corporations have executive committees that meet infrequently, that limit themselves to matters of relatively minor importance, that require formal board approval, that report all their actions to the full board, and that are made up mostly of nonmanagement directors who are selected by the board as a whole. ${ }^{163}$ In appraising a board of directors' role, it would be critically important to know whether the board has an executive committee, and if so, which of these two models it most resembles.

The same can be said of other committees, such as compensation, audit, finance, nominating, and public policy committees, though the considerations of greatest importance with regard to any one committee may depend on the committee and the makeup of the board as a whole. ${ }^{164}$ For example, it is important to know whether the members of an audit committee are selected by the board as a whole where management directors make up a majority of the board, or whether a nominating committee made up completely of unaffiliated nonmanagement directors has been delegated full authority to select new nominees to the board, or whether a compensation committee of nonmanagement directors has been authorized to retain its own legal counsel to review proposed management compensation plans.

Moreover, the information about a board's committee system will be complemented by the proposed disclosures about directors' affiliations with management and the frequency and length of committee meetings. Viewed together, this information should help shareholders and other interested persons to understand the contribution of each committee and its members to the activities of the board.

162. Few data are available about these aspects of board practice. It is interesting to note, though, that the Corporate Director's Guidebook, supra note 50, at 27 , says a "director is entitled to receive a copy of minutes of all meetings of the full board and each board committee (whether or not he is a member)." Yet only 35.6 per cent of the companies responding to recent survey said they provided directors, prior to board meetings, with summaries of action taken by board committees subsequent to the last board meeting. Heidrick \& Struggles, Inc., supra note 44, at 10.

163. The range of practices corporations follow with respect to the organization, authority, and membership of their executive committees is outlined in J. BACON, supra note 44, at 64-68, and J. BACON \& J. Brown, supra note 96, at 105-117.

164. See id. at 117-140 for a discussion of the different roles played in different corporations by audit, compensation, finance, nominating, social responsibility, contributions, and other board committees. For a useful illustration of a framework within which a "well-functioning compensation committee might perform," see Leech \& Mundheim, supra note 53, at 1823-24. 


\section{b. Information Systems}

Information is the lifeblood of a board's activities. Without an adequate flow of accurate information, it is close to impossible for a board to play any meaningful role within a corporation. ${ }^{165}$ A board needs information for two purposes. One is monitoring management's performance, and the other is passing on specific transactions or policy recommendations.

The SEC has an interest in assuring that registrants' boards receive the information they need to meet their obligations under the securities laws, and investors have an interest in knowing whether the board had access to all information it felt it needed. ${ }^{166}$ However, defining thorough standards of general application for what is an adequate flow of information is not feasible, and requiring disclosure of all information that is transmitted to a board is probably neither practicable nor desirable. ${ }^{167}$ Thus, fashioning a disclosure requirement relating to the flow of information to the board presents a formidable problem.

Our recommendation concerning information flows recognizes these problems, and is intended to achieve only a limited objective: to deter the board from serving as a rubber stamp for management's recommendations, and to assist shareholders in determining whether the board is acting in that fashion. ${ }^{168}$ If, for example, a board regularly approves the consummation of major transactions on the basis of information first presented to it at board meetings, we believe the inference can fairly be drawn that the board exercises very little independent judgment in reviewing management's recommendations. ${ }^{169}$

165. See Corporate Director's Guidebook, supra note 50, at 16. See also Heller, supra note 156, at 26: "To make board meetings as effective as possible, each board member should receive an advance information package and should have at least three or four days to study this material before he is asked to act on it at the meeting."

166. In its Report of Investigation Concerning Stirling Homex Corp., the Commission placed great stress on the fact that "There existed no internal system by which they [the outside directors] were regularly provided with significant information concerning corporate affairs. . . ." SEC Securities Exchange Act Release No. 11516, supra note 63, at $₫ 85,462$.

167. See Mace, Management Information Systems for Directors, 53 Harv. Bus. Rev., Nov.-Dec. 1975, at 14, 17 (corporate practice in informing directors varies). For more specific information on the variety of corporate practices in this area, see J. BACoN \& J. Brown, supra note 96, at 89-98; Heidrick \& Struggles, Inc., supra note 44, at 10.

168. Professor Mace reports:

I recently learned of companies which follow the practice of not mailing out anything prior to meetings and requiring that any company information provided at the meeting be turned in prior to leaving the boardroom. The explanation was that directors could not be trusted to observe the confidentiality of sensitive inside information.

Mace, Ideal Board, supra note 125, at 198.

169. See The Board: It's Obsolete Unless Overhauled, Special Report, Bus. WEek, May 22, 1971, at 50, 55 (Quoting Robert E. Brooker, chairman of the executive committee of Marcor, Inc.: "If you're going to have an effective outside board, it must be briefed in advance. It's unfair to ask directors to make decisions only from board discussions.") 
The basic disclosure called for is whether the board regularly receives at least two days in advance of board and committee meetings what it considers to be adequate information about matters management suggests it address at those meetings. If the board regularly receives such information, it would be able to note that fact. (Of course disclosure that the board received information does not guarantee that it then made an independent judgment on the basis of that information. But it at least increases the chance.) However, if there were times when the board authorized or approved material transactions without advance information, we believe shareholders should be informed of those facts. Our guess is that in most such instances the board also would choose to explain to shareholders why it believed taking such action without advance information had been in the shareholder's best interest, even though such explanations would not be required. ${ }^{170}$

\section{c. Monitoring Systems}

Given the importance of the board's monitoring role, it is essential that the disclosure system both encourage boards to play such a role and provide shareholders with the basis for understanding whether and how the board is doing so. ${ }^{171}$

A requirement that registrants disclose the procedures and criteria used by their boards of directors to monitor management's performance should go a long way toward attaining this goal. First, to the extent that the disclosure requirement causes a board to think through and articulate its monitoring process, it will make a major contribution to the institutionalization of that process within the corporation. More than two thirds of the corporations responding to one recent survey reported that they did not have a formal management audit procedure for directors to follow. ${ }^{172}$ Yet as Professors Leech and Mundheim point out: ${ }^{173}$

It is not enough to encourage the chief executive to want to have a board which does an effective monitoring job. The only effective instrument for change is the institutionalization of processes that make it mandatory for the chief executive to account to a strong board.

Once the principal components of the monitoring system have been published, a board would be under considerable pressure to use the system and to explain its actions toward management in terms of the criteria it had announced. For example, if one element of a corporation's evaluation system

170. For example, a board might feel impelled to take a major action without advance information because the corporation faced an unexpected crisis, such as an unexpected tender offer to which management wants to react very quickly. See Wall St. J., June 13, 1977, at 4, col. 1 (Avis board decides not to accept competing tender offer for Avis stock).

171. Eisenberg, supra note 46, at 402-403.

172. Korn/Ferry Survey, supra note 120, at 18.

173. Leech \& Mundheim, supra note 53, at 1827. 
was to "evaluate the performance of the CEO and division president's quarterly, based on comparisons with the performance of competitors, when appropriate competitive information is available," ${ }^{174}$ the board would probably feel compelled to question the performance of a lagging division, and either to change the management of that division or to explain to shareholders why the division was having problems and what the board or management intended to do about them.

Secondly, the description of the procedures used, when combined with information about directors' affiliations and about time devoted to board activities, would provide investors with a good indication of the independence of the monitors and of the amount of time they are devoting to this task. It also would enable investors to know whether a board, or the responsible committee of the board, regularly used the services of persons outside the corporation's management-such as management consultants - to assist it in developing a monitoring system or data to be used in evaluating management's performance.

Finally, publication of the criteria used to evaluate management's performance should provide investors with valuable insights into the corporation's future performance. It is well documented that corporate officials generally are very responsive to the criteria used to rate their performance. ${ }^{175}$ Thus, investors would better understand and predict management's behavior if they knew that a corporation's board evaluated management on any of the following criteria: quarterly, annual, or five-year goals; increases in sales, net income, or return on assets employed or shareholders' equity; development of new products; diversification or consolidation; or responsiveness to social pressures or government programs. ${ }^{176}$ Moreover, while corporations, corporate officials, or researchers have listed all of these criteria as components of their evaluation systems, ${ }^{177}$ several of them are inconsistent with others, and

174. This was one of the responsibilities of the board set out in a model charter for the board of directors. Mace, Ideal Board, supra note 125, at 21 .

175. See, e.g., R. Ackerman, supra note 31 .

176. For a recent illustration of how management evaluation systems influence corporate performance, see Wall St. J., June 1, 1977, at 1, col. 6 (in many corporations evaluation systems stressing return on investment have operated to deter needed investment in new capital equipment).

Information about a board's evaluation system also will aid interested parties in determining whether the board sees its primary responsibility to be preventing financial disasters or driving management to outperform its competitors. See Clendenin, Company Presidents Look at the Board of Directors, 14 Cal. Management Rev., Spring 1972, at 60.

177. See Mace, Ideal Board, supra note 125, at 21-22 (listing numerous factors to be used in evaluating management); IRRC Transcript, supra note 101, at 55 (remarks of Louis V. Cabot, describing evaluation of CEO against a set of 5-year goals); Bauer, Cauthorn \& Warner, Auditing the Management Process for Social Performance, Bus. \& Soc'y Rev., Fall, 1975, at 39 (suggesting a "process audit" of management responsiveness to social pressures); Berkshire Hathaway Corp., 1976 Annual Report to the Stockholder (letter from chairman of the board Warren E. Buffet stating that rate of return on shareholder's equity is "a much more significant yardstick of 
many of them could not sensibly be used together in the unique circumstances presented by individual companies. As a consequence, it seems unlikely that corporations would respond to this requirement with standardized language ("boilerplate"), and to the extent that they do, shareholders and investment analysts are likely to subject their boards and managements to vigorous criticism for failing to develop a consistent set of goals in terms of which the corporation's performance can be evaluated. ${ }^{178}$

\section{d. Staff Assistance}

The lack of institutionalized staff assistance caused Arthur J. Goldberg to resign from the board of directors of TWA. ${ }^{179}$ Justice Goldberg advocated the creation of a staff of professionals who would serve the outside directors of the corporation, thereby enhancing their independence. There was much adverse comment on the proposal, ${ }^{180}$ but most of the criticism was focused on Goldberg's proposal that the staff be independent from the company.

The desirability of providing staff assistance has gained significant support. General Motors furnishes its board committees with considerable employee assistance, although no one is assigned to assist the board on a permanent basis. ${ }^{181}$ When asked at an annual meeting what kind of staff assistance GM's Public Policy Committee received, Chairman James Roche responded, "They have access to all the staffs in General Motors for whatever purpose they may require." ${ }^{82}$ Robert Estes, former general counsel of General Electric Company, has urged the assignment of counsel to the outside directors, since so much of what properly concerns them involves legal issues. ${ }^{183}$

It does seem clear that the judgments directors are required to make involve complex matters on a wide range of subjects. No busy director, not even the most versatile, can give proper attention to all these matters without some assistance. He can obtain it on his own, or he can follow the lead of other,

economic performance" than total operating earnings). Cf. RCA's New Vista: The Bottom Line, Bus. WEEK July 4, 1977, at 38 (noting a shift in RCA Corp.'s strategy away from promoting technological innovation in favor of increasing short-term earnings, which RCA's annual report "subtly underscores" by featuring a cover picture of a Hertz Corp. airport bus, rather than the traditional picture of some aspect of RCA Corp. technology).

178. If a board can demonstrate that it acts as an independent monitor of management's performance, management, too, would benefit in that proof of board review would effectively insulate management's decisions from judicial second-guessing, if those decisions are challenged by shareholders. See Leech \& Mundheim, supra note 53, at 1805.

179. Goldberg, supra note 42.

180. See Blough, The Outside Director at Work on the Board, 28 Recond of N.Y.C.B.A. 202 (1973); Smith, The Goldberg Dilemma: Directorships, Wall St. J., Feb. 7, 1973, at 14, col. 3; Eisenberg, supra note 46, at 390 . But see Schwartz, A Plan to Save the Board, 28 ReCord of N.Y.C.B.A. 279 (1973).

181. Leech \& Mundheim, supra note 53, at 1808.

182. Transcript of Annual Meeting of GM Stockholders, May 21, 1971, at 281 (on file with the authors).

183. Estes, supra note 106. See also IRRC Report, supra note 114, at 42. 
more knowledgeable colleagues on the board, but both of these methods seem chancy. Alternatively, the corporation can provide staff assistance. What is done in this regard seems to us to bear on the professionalism and performance of the outside directors, the board, and the corporation.

\section{Information About Directors' Resignations ${ }^{184}$}

\section{a. Explanation of the Proposal}

Finally, we have proposed that the Commission impose on registrants new disclosure requirements relating to directors' resignation and retirement. Registrants would be required to list all directors who have left the board since the last annual meeting or are not standing for reelection, and to state the reasons why each of them has taken such action.

These disclosure requirements would differ from the others we have proposed in that each of the other requirements was to some degree oriented toward affecting a director's or a board's conduct in a particular way. Here the purpose of our proposed requirement is not to encourage or discourage directors to resign, and we do not believe there is any sound basis for predicting that it would have either of those effects.

Moreover, the other disclosure requirements we have proposed are designed to assist shareholders in understanding whether and how individual directors and the board are meeting their legal responsibilities. No analogous legal standard relevant to the proposed disclosure requirements governs resignations. Specifically, it is well established that directors are free to resign for any reason they choose, ${ }^{185}$ so long as they do not resign to secure some private pecuniary gain ${ }^{\mathbf{1 8 6}}$ or as part of a plan to transfer control of the corporation to persons who they have reason to believe will manage the corporation in a manner that is adverse to the interests of the shareholders. ${ }^{187}$

However, although the proposed requirements do not aim to influence directors' decisions to resign, we believe they would serve two important purposes. First, they would strengthen the independence of the board by strengthening the position of directors within the corporation. Second, they

184. The proposed requirement would apply to resignations, retirements, situations where a director chooses not to stand for reelection, and situations where the persons in control of the registrant's proxy materials do not nominate a director for reelection. Registrants also should be required to file the information required by this section in a Form $8-\mathrm{K}$ since the information may be material to ongoing investment decision-making. $C f$. SEC Accounting Series Release No. 165 [1977] FED. SEc. L. REP. (CCH) I 72,187 (Dec. 20, 1974), requiring increased disclosure in Form 8-K relating to registrants' changes of independent public accountants.

185. "A director or other officer of a corporation may resign at any time and thereby cease to be an officer. ..."W. Fletcher, 2 Cyclopedia of the Law of Private Corporations, $\$ 345$ (1969).

186. Id. § 348; Essex Universal Corp. v. Yates, 305 F.2d 572 (2d Cir. 1962).

187. Gerdes v. Reynolds, 28 N.Y.S.2d 622 (Sup. Ct. 1941). 
would ensure that potentially significant information about a corporation or its board is made available to investors.

The SEC has recognized for some years, in the case of registrants' independent public accountants, that required disclosure about the circumstances under which a registrant has changed accountants can enhance the independence of accountants. In late 1971 the SEC instituted a requirement that companies report a change in the auditors who certified their most recent financial statements. ${ }^{188}$ In late 1974 the Commission amended and strengthened that requirement. ${ }^{189}$ After noting that "[o]ne of the underpinnings of the Commission's administration of the disclosure requirements of the federal securities laws is its reliance on the reports of independent public accountants on the financial statements of registrants," the Commission stated that "to enhance the accountant's independence," registrants should be required to report the resignation or dismissal of their principal accountants and the details of any "significant disagreement" between registrants and their accountants during the past two years. ${ }^{190}$ This requirement was intended to deter registrants from dismissing their accountants because they did not like the accountants' proposed treatment of some matter or the accountants' stated intent to qualify their opinion. It also was intended to notify investors of the existence of a dispute where it had led a registrant to change accountants. ${ }^{191}$

A nonmanagement director of a corporation who attempts to exercise independent judgment is in a position similar to that of the independent public accountant - that is, the director is weak because his activities primarily benefit persons other than management (i.e., the shareholders) and because he must obtain the support of a majority of the board. ${ }^{192}$ Management, which may control the proxy process or command the loyalities of a majority of the board, has little stake in allowing or encouraging the director to pursue activities that it views as prejudicial to its interests. One approach to strengthening the director's position is to provide him with a new base of power by ensuring that his point of view will be provided to investors. A disclosure requirement in this area should discourage a corporation's management from denying directors' legitimate demands or from pressuring a director or the

188. Item 12, Form 8- $\mathrm{K}$ was adopted in SEC Securities Exchange Act Release No. 9344, [1971-72 Transfer Binder] FED. SEC. L. REP. (CCH) ๆ 78,304 (Sept. 27, 1971) (now renumbered as item 4).

189. SEC Accounting Series Release No. 165, [1977] FEd. SEC. L. ReP. (CCH) I 72,189 (Dec. 20, 1974).

190. Id.

191. For a discussion of the requirement, see Hawes Stockholder Appointment of Independent Auditors:" A Proposal, 74 Colum. L. Rev. 1 (1974); Hawes, Changing Auditors, 7 Rev. Sec. Reg. 935 (1974).

192. For an enlightening analysis of the dynamics of the auditor-management relationship, see Nichols \& Price, The Auditor-Firm Conflict: An Analysis Using Concepts of Exchange Theory, 51 Accounting Rev. 375 (1976). 
board as a whole to behave in an inappropriate fashion. ${ }^{193}$ It gives bite to a director's conscience-driven threat to resign unless certain reforms are instituted or certain disclosures made.

The proposed disclosure requirement will also ensure that shareholders are informed when one or more of the persons they have elected as directors are leaving a board because they have serious misgivings about the activities or organization of the corporation or its board. The social ethic that now discourages controversy even within the boardroom creates a barrier that, in general, assures that all but the most independent directors will decline to go public about the concerns that have caused them to leave a corporate board. ${ }^{194}$ The director who is uncomfortable about his position is more likely to resign quietly or to decline to stand for reelection. Yet it seems clear that the concerns that lead a director to resign may be of considerable interest to shareholders and to those considering purchasing the stock of the corporation.

The resignation of Robert Odell from the board of the Penn Central Company illustrates dramatically the problems our proposed requirement would alleviate. ${ }^{195}$ Odell resigned in 1970 when his inquiry into Penn Central's involvement with Great Southwest Corporation was frustrated by both manage-

193. Nichols and Price state that one approach to increasing the power of the auditor is to increase "the ability of a replaced auditor to cause sanctions to be imposed on the firm resulting from unjustified replacement." Id. at 344. They cite the SEC rules governing replacement of auditors as an example of this approach. They conclude, though, that these procedures will have variable success. $I d$. at 345 . Similarly, the existence of the proposed disclosure requirements will not ensure that directors will assert their independence.

Nichols and Price suggest two other ways to influence the balance of power between auditors and firms, both of which also are suggestive of steps that might be taken to strengthen the position of directors. The first would be to increase the expected cost to the auditor of taking inappropriate actions, for example by providing "greater specification of auditing and accounting standards." Id. Similarly, directors' behavior might be influenced by making more clear the legal responsibilities of directors. The second would be to change "the structure of the auditor-firm contractual relationship" by shifting away from management the responsibility for selecting auditors. Id. As we discussed above, similar changes relating to the selection of directors appear quite promising. See notes $148-50$ supra, and accompanying text.

194. We can recall only two instances in which nonmanagement directors announced publicly that they had resigned from a corporate board because of concern about corporate or board activities. One was Arthur J. Goldberg's resignation from the board of TWA because he thought outside directors should be provided with their own staffs and with better access to information about major corporate decisions. Goldberg, supra note 42. The other involved Norton Simon's decision to resign from the board of Burlington Northern. The company circulated to its shareholders a statement written by Simon setting out his disagreements with the business strategy Burlington Northern was pursuing. Burlington Northern, Inc., Report on Fourth Annual Meeting (held May 10, 1973). Apparently, Simon also brought his concerns about the accounting practices being used by Burlington Northern to the attention of the enforcement staff of the SEC, which after investigation, brought an enforcement action against the company. See also Burlington Northern Accepts SEC Order Involving Disclosure, Wall St. J., April 29, 1977, at 16, col. 3.

195. This incident is described in considerable detail in STAFF of THE SEC, supra note 60. 
ment and fellow directors. ${ }^{196}$ Odell's inquiry would have uncovered Penn Central's massive real estate losses and its manipulation of Great Southwest to conceal them, ${ }^{197}$ but his misgivings-though clearly expressed to management and board-were not related to the shareholders until after Penn Central had declared bankruptcy. Our proposed requirement would have discouraged the management from bringing Odell to the point of resignation; or once he resigned, his reasons would have been explained publicly. ${ }^{198}$

\section{b. Framing the Requirement}

A key issue in drafting the proposed disclosure requirement concerning directors' resignations is that registrants should feel compelled to report the factors affecting resignations of directors that are likely to be of legitimate interest to shareholders. The SEC faced a similar issue when it drafted its regulations about registrants' relationships with their auditors. In that case the Commission decided not to require a registrant to disclose the reason for every change of auditors, largely because many changes are made because of disagreements about auditor's fees, and the Commission concluded registrants should not be required to explain their decisions in those situations. ${ }^{199}$ Eventually, the SEC decided to require detailed disclosure only if during the two years prior to the change of accountants, there had been a disagreement between the registrant and its accountant about a matter which, had the disagreement not been resolved in favor of the accountant, would have resulted in the accountant qualifying his opinion. ${ }^{200}$

The standard adopted by the SEC to define when detailed disclosure is required in the case of a change of accountants has given rise to a number of interpretive problems, ${ }^{201}$ yet it probably is more precise than any standard

196. "The other directors paid little attention to the whole matter, particularly because Odell was 'solving' the problem for them by leaving." Id. at 170 .

197. For details of Penn Central's involvement with Great Southwest Corp., see id. at 121-150.

198. We do not intend to suggest that any of these consequences would have prevented the collapse of the Penn Central, but they might have helped to limit some of the damage done by management's deception, including the almost disastrous impact on financial markets of the company's seemingly sudden collapse. $I d$. at viii-x.

See also the letter of another director, Louis Cabot, to the chairman of Penn Central, id. at 164-65 (expresses concern about the relationship between Penn Central's management and board).

199. See Bedingfield \& Loeb, Auditor Changes-An Examination, 137 J. Accountancy 66, 67-68 (1974).

200. SEC Accounting Series Release No. 165, [1977] Fed. SEC. L. ReP. (CCH) I 72,187 (Dec. 20, 1974). The Commission has apparently reconsidered that decision. It recently proposed to amend its rules to require that the reason for an auditor's resignation be made public in all cases. SEC Securities Act Release No. 5868 [1977] Fed. SEC. L. ReP. (CCH) ף 81,305 (Sept. 26, 1977).

201. These problems are discussed in Kay, Disagreements Under Accounting Series Release No. 165, $142 \mathrm{~J}$. Accountancy 75 (1976) and Weiss, Disclosure Surrounding a Change in Auditors: Accounting Series Release 165, 45 CPA J. 11 (1975). 
that might be developed to define which reasons for a director's decision to leave a board are likely to be of interest to shareholders. Consequently, patterning the disclosure requirements here on the approach the SEC has followed with respect to changes of accountants does not appear to be an available course.

A better approach, we believe, would be to require a statement of the reasons why each director has left the board and, if factors involving the operations of the corporation or the organization or activities of its board of directors bore no significant relationship to the director's decision to leave, to require an affirmative statement to that effect. Requiring an explanation of all resignations should not cause any severe problems, as it is difficult to see how anybody would be discomforted by a disclosure that a director resigned "for personal reasons" or "due to the press of other commitments"-the factors that probably motivate most resignations. ${ }^{202}$ At the same time, requiring a statement that no factors of a kind likely to be of interest to investors bore a significant relationship to the director's decision should maximize the pressure on registrants to disclose any such factors, since making a false or misleading statement in this regard could give rise to liability under the antifraud provisions of the securities laws.

Thus, if a director resigns because of a dispute over corporate strategy, because of concerns that the board is not receiving adequate information about the corporation, because he disagrees with the system used by the board to evaluate management's performance, because he feels the board tries to involve itself too deeply in the details of managing the corporation's business, or for other comparable reasons, the registrant would include a statement to that effect in its proxy statement. Moreover, to further safeguard the integrity of the process, registrants would be required to provide a director who has left the board with a draft of the statement explaining his action, and either to report that the director does not dispute the statement or to circulate to shareholders a statement prepared by the director setting forth his point of view.

\section{c. Potential Problems}

There are three problems which, we believe, some might suggest will be caused by requiring disclosure about directors' resignations. One is that cor-

202. These explanations probably could legitimately cover those situations where a director has been fired because he has not made a sufficient contribution to the board. Heidrick and Struggles asked the companies it surveyed if they had ever fired a director and received the following responses:

None ever fired

$63.6 \%$

Resignation requested

$19.2 \%$

Not renominated

$12.5 \%$

Asked not to run again

$10.1 \%$

Size of board reduced

$2.7 \%$

Other

$0.3 \%$

Heidrick \& Struggles, Inc., supra note 44, at 12. 
porate managements, fearful of what might have to be disclosed, will withhold important information from boards to prevent controversy. Second is that because of concern about these disclosure requirements, competent people will decline to serve on boards. Third, there is the risk that the power given directors will be abused. In our view, none of these concerns has merit.

As we pointed out above, information is the lifeblood of a board's operations. The absence of an adequate flow of information, perhaps more than any other factor, is likely to lead directors to resign. ${ }^{203}$ Moreover, to the extent that directors are becoming more concerned about meeting their responsibilities under state corporation laws and the federal securities laws, they are apt to insist on receiving more information from management. Given these factors, we do not give credence to the argument that managements will be able to withhold important information from their boards of directors.

Similarly, we do not believe these disclosure requirements will make it more difficult for registrants to find competent nonmanagement directors. The argument that the supply of directors will dry up is made virtually every time any action is proposed to increase directors' obligations. ${ }^{204}$ Curiously, this argument is made in response to a proposal that will not so much increase the responsibilities of outside directors as increase their power. The best answer to it is that people should not accept positions that involve substantial responsibilities to others, such as corporate directorships, unless they are willing to make the effort required to acquit themselves of those responsibilities. ${ }^{205}$ Surely we should not endeavor to maintain a system in which the directors are little more than figureheads. A second response, applicable to this situation, is that if this and other changes are made in the institutional framework to provide directors with an opportunity to play a more constructive role, more competent people are likely to demonstrate an interest in becoming directors. ${ }^{206}$ Thus, instead of drying up the supply, the proposed change is likely to increase it and to contribute in another, indirect fashion to the revitalization of registrants' boards of directors.

203. The Corporate Director's Guidebook. supra note 50, at 22, mentions only one situation in which a director "in all likelihood should consider resigning." It is when "he believes that adequate information is not being provided . . and is unsuccessful in his efforts to remedy that situation..."

204. See, e.g., Estes, Outside Directors: More Vulnerable Than Ever, 51 Harv. Bus. REv., Jan.-Feb. 1973 , at 107 .

205. See Address by SEC Chairman Ray Garrett, Jr., supra note 60.

206. See C. Brown, supra note 44 , at 90 :

[I]t is no doubt true that, if the attractiveness of board membership were enhanced, many highly competent people would seriously consider second careers as professional directors after early retirement from a variety of first career experiences. ...

The possibility of a second career, involving a release from routine activities, the prospect of living with intellectually exhilarating challenges, and an opportunity to share in constructive leadership, would serve as a powerful magnet to attract experienced and talented people and, in time, enlarge the pool of those eligible for board positions in the future. 
Finally, there is the fear that misguided directors will carry their threat to resign to a point where management must yield or face needless embarrassment. Not every minority director will be as right as Odell. No doubt management could describe instances where outside directors were eased out quietly because of incompetence and where the tale was best left untold. We are convinced that the risk must be incurred, especially since management can counter foolishness with its version of the facts. As with our other recommendations which incur the risk of abuse, we think the potential gain outweighs the costs. 